\title{
Illegal Trade in the Iranian Economy: Evidence from a Structural Model
}

\author{
MOHAMMAD REZA FARZANEGAN
}

CESIFO WORKING PAPER NO. 2397

CATEgORY 7: TRAdE POLICY

SEPTEMBER 2008

Presented AT CESifo VeniCE SumMer Institute 2008, WORKSHOP ON

'ILLICIT TRADE AND GLOBALISATION'

\footnotetext{
An electronic version of the paper may be downloaded

- from the SSRN website:

- from the RePEc website:

- from the CESifo website:

www.SSRN.com

Www.RePEc.org

www.CESifo-group.org/wp
} 


\title{
Illegal Trade in the Iranian Economy: Evidence from a Structural Model
}

\begin{abstract}
This study investigates the main causes and consequences of import and export smuggling and estimates the relative index of smuggling in Iran from 1970 to 2002. The Multiple Indicators - Multiple Causes (MIMIC) econometric modelling is used for a comprehensive analysis of the latent variable of smuggling. The main results of this paper indicate that the rate of fine for smuggling and the general level of education reduce smuggling, while the tariff burden increases the incentives for illegal trade. More trade openness accompanies more illegal trade for the case of Iran. On average, the relative size of smuggling is about $13 \%$ of the total trade in Iran. The absolute amount of smuggling per year is about \$3 billion.
\end{abstract}

JEL Code: O17, C39, H26.

Keywords: smuggling, structural equation model, Iran, illegal trade.

\author{
Mohammad Reza Farzanegan \\ Dresden University of Technology \\ Faculty of Business and Economics \\ Chair of Economics esp. Public Economics \\ 01062 Dresden \\ Germany \\ Mohammad_Reza.Farzanegan@mailbox.tu-dresden.de
}

This version 14.08 .08

I wish to thank Mohammad Akhbari, Hadi.S. Esfahani, Annabel Payne, Marcel Thum, and participants in the Labsi International Conference on Political Economy (2007, Italy), 14th Annual Conference of ERF (2007, Egypt), and European Public Choice Conference (2008, Germany) and CESifo workshop on "Illicit Trade and Globalization" (2008, Italy) for their invaluable comments. The financial support of German Academic Exchange Service (DAAD) and CESifo is highly appreciated. The remaining errors are mine. 


\section{Introduction}

Smuggling can be defined as the clandestine import of goods from one jurisdiction to another (Deflem and Henry, 2001). Another definition says that smuggling is the evasion of excise taxes on goods by circumvention of border controls (Merriman, 2003). Regardless of different approaches to definitions of this complex multi-aspect issue, the effects of smuggling are numerous and economically significant. For instance, smuggling creates losses in public revenues, it affects the internal structure of a society by creating powerful illegal institutions, and it changes the patterns of consumption (Dominguez, 1975). Furthermore, it may have a negative effect on official indicators such as growth and income distribution.

It can be argued that the primary forces of supply and demand drive smuggling. Whenever state intervention drives a wedge between international and domestic prices (through excise duties, trade restrictions and custom duties), there is an incentive for underground activities. Smuggling is an activity that is used to earn income from carrying goods through the state border in violation of existing rules. Smugglers seek to generate income by avoiding state control, regulations and related costs (Lithuanian Free Market Institute, 2004). It involves bribery and other forms of corruption and is of a criminal nature.

While a large body of literature is devoted to theoretical aspects of the effects of smuggling on social welfare ${ }^{2}$, this paper estimates the determinants and effects of smuggling in a natural resource abundant economy. Estimating smuggling is challenging because it is an illegal and hidden activity. A number of methods to estimate smuggling are available, but each method has its limitations. The methods usually applied to estimate smuggling can be classified through direct and indirect approaches. Direct methods are based on contacts with or observations of persons and/or firms, to gather direct information about smuggled products. We can categorize the indirect methods of estimating smuggling as: (1) discrepancies between the sale of goods under study and the estimated consumption of those products by using household surveys; (2) discrepancies between the sale of goods and the estimated consumption of those products by using econometric estimation; (3) discrepancies between the trade figures of the target country with her trade partners in order to find "mis-invoicing"; and (4) the model approach or MIMIC (Multiple Indicators and Multiple Causes) method.

The principal technique of detecting illegal trade - the partner country data comparison technique has its origins in the work of Morgenstern (1950) on the accuracy of foreign trade statistics. The technique was further developed by Bhagwati (1964) and Naya and Morgan (1969). Bhagwati (1964) compared the import data of Turkey from the other countries with the recorded figures of export from trade partners of Turkey. He found under-invoicing in Turkey's official imports. Naya and Morgan (1969) followed a similar methodology for the case of South East Asian countries. They observed

\footnotetext{
${ }^{2}$ For example, Bhagwati and Hansen (1973), Bhagwati and Srinivasan (1973), Martin and Panagariya (1984), Norton (1988), and Thursby and Thursby (1991), to name a few.
} 
irregular patterns in this region's trade, suggesting a large degree of inaccuracy and discrepancy in trade data.

Alano (1984) carried out an econometric analysis of import smuggling in the Philippines during 19651978. The dependent variable in his study is import smuggling that was calculated based on partnercountry trade data discrepancies. This information was generated by comparing export figures of major trade partners of the Philippines with import figures of this country from them. His estimation of smuggling for the Philippines ranged from $28.95 \%$ to $53.81 \%$ of the reported exports to this country from the partner countries. His results support the dominant role of technical smuggling through legal trade channels hypothesis in the case of the Philippines. Phylaktis (1991) developed a stock-flow model on the base of Dornbusch et al. (1983) model and error correction model (ECM) to explain the determinants of black market premium in Chile. Among the important determinants of black market premium, she emphasized on the role of import smuggling. According to her words "tariffs by encouraging import smuggling, tend to increase the black market premium, which in turn motivates exporters to direct export earnings to the black market".

Yavari (2000) followed the methodology of Bhagwati (1964) and estimated over-valuation of imports in Iran for the period of 1977-1997. His calculation of import mis-invoicing shows a different pattern before and after the final year of war with Iraq (1988). While, before this year, we can observe both under-invoicing and over-invoicing of imports, the most years after 1988 demonstrate the dominant share of over-invoicing of imports. By using import tariff as a proxy for smuggling in a panel data for 70 developing countries from 1956 to 1998, Oskooee and Goswami (2003) demonstrated the positive effect of smuggling on the black market premium. Madah and Pajoyan (2005) examined smuggling in Iran through structural equation approach. They calculated an ordinal trend of import smuggling by using three causal variables, namely rate of fine, ratio of official to black exchange rate and import tariff. They obtained the negative effect of fine rate and positive effect of the last two casuals on smuggling. However, the authors did not estimate the relative size of smuggling and absolute figure of it throughout the period. This step needs further estimation of (import and export) smuggling with another methodology such as trade discrepancy to transform the ordinal index to relative index of smuggling. They also failed to control for standard variables like GDP per head, trade openness and human capital. In addition, their study is focusing on import smuggling, ignoring the export smuggling. Finally, although the authors admit that the causal variables are not stationary but they estimated the ordinal index with the level of variables. This requires the existence of cointegration among indicator and casual variables, which is not provided by them.

Our contribution is estimate of import and export smuggling size (relative and absolute) in total trade of Iran by including more standard variables which may affect smuggling, controlling for exogenous shocks of revolution (1979), war with Iraq (1980-1988), the major revision of smuggling punishment regulation in 1993/94 and unification of exchange rates (2002). Meanwhile, we estimate mis-invoicing (under and over invoicing of both exports and imports) in Iran to transform the ordinal index of 
smuggling in Iran. In addition, we examine specific effects of smuggling on the real government revenue, real tax revenues, real import price index and growth rate of gasoline consumption. The analysis uses the annual data for the case of Iran over the period of 1970-2002.

The paper is organised as follows. In section 2, stylized facts of the Iranian economy that make it an interesting case for study smuggling is presented. Section 3 reviews the theoretical literature on smuggling. The empirical methodology is presented in section 4 . The empirical model and explaining the variables are presented in section 5. Finally, empirical results and main conclusions are presented in sections 6 and 7, respectively.

\section{Stylized facts on Iran}

\subsection{Rules and regulations for smuggling in Iran}

The illegal transaction happens in order to avoid legal taxation and duties for those goods which can be imported legally. However, there is also an incentive for smuggling those goods that are prohibited based on legal or religious grounds such as alcoholic beverages and drugs in the case of Iran. The main relevant rules and regulations in Iran about smuggling are "Penal codes on smuggling" (1933), "Custom rule" (1971), and "Governmental discretionary punishments rule" (1994). The 1933 punishment rule for smuggling identified different kinds of smuggling. This classification covers the following groups: (1) the smuggling of legal products; (2) the import smuggling of illegal products; (3) the export smuggling of illegal products; (4) the smuggling of monopoly products; and (5) special activities.

The smuggling of legal products is the import or export of those products for which the government accounts for custom duties and taxes at the time of the preparation of annual budgets. In fact, these products can be traded legally through payment of official duties and taxes. Smugglers evade legal import taxes and custom duties in this case. Legal products may also be categorized into two groups. First are those goods which do not need the permission of relevant governmental organizations for importing or exporting. These groups of goods will be determined by the Ministry of Commerce in annual import and export regulations at the beginning of each year. After the approval of the Council of Ministers, the list of these goods will be announced to national customs. Second are conditional legal products. These are legal products, which because of a special situation in the domestic economy and general socio-political policies, need prior permissions by governmental organizations. For example, the import of special machinery products or medicines may require permission from the Ministry of Industry and Mines and Ministry of Health, respectively. The second and third groups are the import and export of illegal products. Custom rule has determined these products. Some examples of imported illegal goods are military weapons, drugs and anti-religious or materials printed which are opposed to social norms (books, magazines and so on). In custom rule, we can hardly find any 
concrete example of export smuggling of illegal goods. In general, export smuggling of illegal goods refers to the export of those products that are prohibited based on religious or governmental rules. The fourth category is the smuggling of monopoly products. Monopoly products are those goods which based on monopoly regulations (such as the monopoly of tobacco rule, 1931) can be traded only by the government. Thus, trading such products without having the legal representation of the government is referred to as trading smuggled goods. Finally, the last category are some special activities which are not smuggling in theory but based on the perspective of the authorities will be treated as smuggling in practice. For example, Article 48 of Jungles Protection and Maintenance rule of 1985 declares that "transport of woods and gained coals from trees out of cities without licence from the Forestry Organization will be punished like a smuggling act". Another example is Article 1 of "Penal codes of sellers of anti-religious or anti-public decency textiles". The economic agents who import, produce, or sell such textiles are offenders and these textiles are treated as smuggled goods.

\subsection{Punishment codes for smuggling}

The main regulatory development to combat the smuggling of goods and foreign exchange was realized through the governmental discretionary punishments of 1994 and its executives' guidelines in 2000. Based on this regulation, the penalty for smuggled goods depends on the value of goods and these fall into two groups: (1) products with the value of equal to or less than 10 million rials ${ }^{3}$, and (2) products with a value beyond 10 million rials.

\subsubsection{Products with the value equal to or less than 10 million rials}

Upon the detection of this group of products by the relevant governmental bodies (customs or police), they can seize the goods and inform the government revenues recipients' offices. In this case, related official bodies without extra monetary penalties will seize the detected consignment. Based on articles 12 and 20 of executives' guidelines of governmental discretionary punishments, the governmental revenues recipients' offices must transfer the seized smuggled goods to "possessory goods seller organization",

\subsubsection{Products with a value of over 10 million rials}

In this case, according to the governmental discretionary punishments rule (approved in 1994) governmental revenues recipients' offices, besides seizing the smuggled consignment, will also receive

\footnotetext{
${ }^{3}$ For more information on the value of the rial see : http://cbi.ir/exrates/rates_en.aspx

${ }^{4}$ This organization is affiliated with the Ministry of Economic Affairs and founded in 1991 as a governmental company. The headquarters of this company are in Tehran. The main functions of this company are the gathering, managing and selling of abandoned governmental and non-governmental as well as confirmed smuggled products.
} 
the cash penalty. The cash penalty is twice the value of smuggled products. In this case, the offender may accept or reject to pay the fines. In the former case, upon payment of the penalty, the offender will receive an official fine receipt and will be free of any other judicial prosecution. In the latter case, the case will be sent to court within 5 days upon detection. In the case of confirmation of a smuggling offence, the offender will be sentenced to imprisonment besides seizing the smuggled products or foreign exchange. Furthermore, they must pay the amount of monetary penalty, which will not be lower than twice the value of smuggled products.

\subsection{The main contributing factors to smuggling in Iran}

Tariffs and non-tariffs barriers, strict controls of foreign exchange transactions, pervasive corruption, and high price disparity among Iran and her neighbours because of considerable subsidies on fuel products are recognized as the main reasons behind the smuggling in Iran. A study by Doing Business (2008) has examined the comparative situation of Iran in a term of international trade. Among 178 economies, the ranking of Iran is 135, while UAE, Saudi Arabia and Jordan perform much better and have a ranking of 24, 33, and 59, respectively. Regarding comparative statistics of import cost (USD per 20 - foot container) in the MENA (Middle East and North Africa), only Iraq performs worse than Iran. While the best practice economy is Singapore with the cost of 367 USD per importing container, Iran has the cost of 1330 USD for the same container. These costs cover documents and administrative fees for customs clearance and technical control, terminal handling charges and inland transport excluding tariffs or trade taxes. The required time for the import of products into Iran is 42 days, while in the best practice economy, Singapore, the process lasts for only 3 days. Export process in Iran has the same properties. Table 1 shows the comparative international trade costs of Iran.

Besides tariffs and non-tariffs burden on imports of legal products, foreign exchange market in Iran is the other main factor, which affects the incentives for illegal trade. The foreign exchange premium experienced unique records during the 1980s and 1990s in Iran. For example, the difference between the price of USD in rials in the black and official market reached a figure of 2170 percent in 1992. Biswas and Marjit (2007) have explained theoretically the interconnection between the black market premium and mis-invoicing of foreign trade. In such an environment, the exporters have incentives to under-invoice their real amount of exports to sell the unreported exports in the black market for higher profit. In fact, the export smugglers are suppliers of foreign exchange in the black market. The other important supply channels in the black market are through over-invoicing imports, exchange by foreign tourists, or diversion of remittance via unofficial channels, and diversion by government officials in exchange for bribes. In Iran however, during the high black market premium years, the government was also another main player. The government as a sole receiver of petro-dollars covered some part of the budget deficits through selling the dollars in the black market instead of in the official market under the title of "other revenues" in the annual budgets. 
Table 1: Comparative International Trade Costs

\begin{tabular}{l|c|c|c|c|c|c}
\hline \hline & Documents for & Time for & Costs to & Documents for & Time for & Costs to \\
exports & exports & export (\$ per & imports & imports & imports $\$$ \\
(numbers) & (days) & container) & (numbers) & (days) & container) \\
\hline
\end{tabular}

Best practice economies

\begin{tabular}{|c|c|c|c|c|c|c|}
\hline Canada & 3 & & & & & \\
\hline China & & & 390 & & & \\
\hline Denmark & & 5 & & 3 & & \\
\hline Singapore & & & & & 3 & 367 \\
\hline Iran & 8 & 26 & 860 & 10 & 42 & 1330 \\
\hline \multicolumn{7}{|c|}{ Comparative economies } \\
\hline Jordan & 7 & 19 & 680 & 7 & 22 & 1056 \\
\hline Oman & 10 & 22 & 665 & 10 & 26 & 824 \\
\hline UAE & 7 & 13 & 462 & 8 & 13 & 462 \\
\hline
\end{tabular}

Source: Doing Business in Iran, 2008.

The share of "other revenues" in the annual budgets increased from an average of $14 \%$ between 19781988 (revolution and war period) to 36.2\% during 1989-1992 (Valadkhani, 2004). When we want to examine the mis-invoicing of exports and imports in Iran, we should also pay attention to the relative size of the premium to non-oil export bonus and tariff burden. If the premium in the black market outweighs the export bonus, then there is an incentive for the under-invoicing of exports. Meanwhile, when the premium outweighs the tariff rate, there would be an incentive for import over-invoicing. Of course, the exact effect of the premium in the black market on the illegal imports is not clear. On the one hand, we may expect that those importers who have access to the official banking system for opening an L/C (Letter of credit) try to misprice their real imports through over invoicing. This may enable them to acquire more subsidized exchange, some part of which will be sold in the black market of foreign exchange. On the other hand, for those illegal importers who do not have access to subsidized exchange, the increasing premium means an increasing financing cost of illegal import. In the latter case, an increasing premium will not be an incentive for mis-invoicing, but an extra cost burden on import smugglers. Figure 1 shows the trend of premium in the black market of US dollar for the period of 1970-2006 in Iran. 


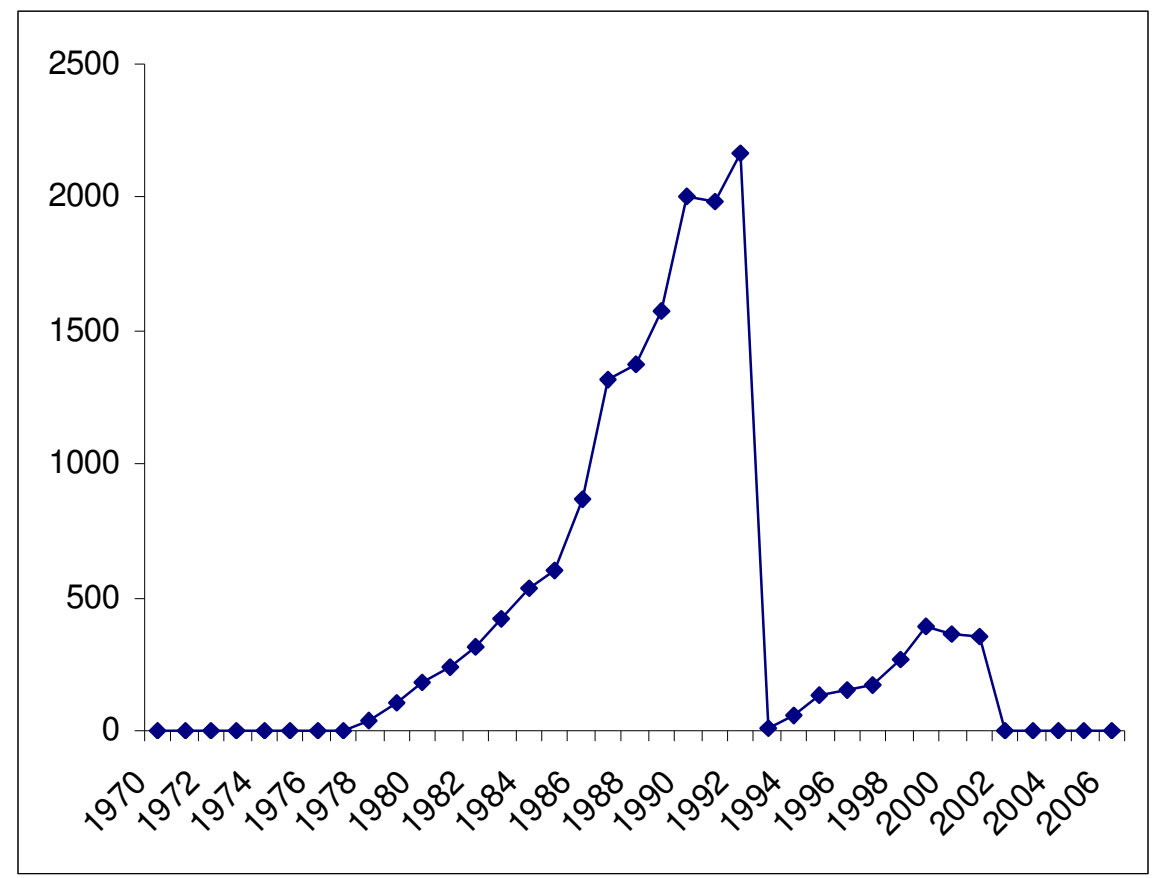

Figure 1: Black Market Premium (percentage)

Source: Central Bank of Iran (2008)

Since the unification of the exchange rate in 2002, the black market premium has reduced substantially. Now the main motivation for import and export smuggling in Iran is the high tariff burden for protecting the domestic industries and producers, a continuation of subsidies on fuel products in Iran and export bonus for non-oil exporters. For example, the detected export misinvoicing in Khoramshahr Custom (South-west of Iran in Khouzestan province) over the two years of 2006 and 2007 is 1.2 billion USD. Another example in the mentioned custom is related to an exporter who reported 10 million USD exports and benefited from export bonuses; however, it was cleared after investigation that he has not exported any amount of materials, mis-invoicing the 10 million USD through a corrupt deal with custom officers. ${ }^{5}$

Another important factor for expanding the smuggling out of Iran is a large price disparity between Iran and her neighbours because of subsidies on fuel products. Around $90 \%$ of export smuggling in Iran belongs to oil related products. Table 2 shows the main import and export smuggled goods in Iran in the year 2005 .

${ }^{5}$ www.rajanews.com/News/?27704 (Persian News Agency, access: 2 June 2008) 
Table 2: The 10 Largest Detected Illegally Imported-Exported Goods (2005)

\begin{tabular}{|c|c|c|c|c|}
\hline No. & Import smuggling & $\begin{array}{c}\text { Share of total } \\
\text { detected import } \\
\text { smuggled goods } \\
(\%)\end{array}$ & Export smuggling & $\begin{array}{l}\text { Share of total detected } \\
\text { export smuggled goods } \\
(\%)\end{array}$ \\
\hline 1 & Machinery & 24 & Gas oil & 60.6 \\
\hline 2 & Car & 12 & Kerosene & 17.6 \\
\hline 3 & $\begin{array}{l}\text { Alcoholic } \\
\text { beverages }\end{array}$ & 9 & $\begin{array}{c}\text { Other petroleum } \\
\text { products }\end{array}$ & 11 \\
\hline 4 & Piece (cloths) & 8.5 & Gasoline & 2.5 \\
\hline 5 & $\begin{array}{l}\text { Chemical } \\
\text { materials }\end{array}$ & 8 & Gold bar and clutch & 1.5 \\
\hline 6 & Accessory & 4.7 & Other goods & 1.2 \\
\hline 7 & Clothing & 3.7 & Car & 1.1 \\
\hline 8 & $\begin{array}{l}\text { Gold bar and } \\
\text { clutch }\end{array}$ & 3.1 & Sugar & 0.8 \\
\hline 9 & Tea & 3.1 & Iron and clutch & 0.5 \\
\hline 10 & Cereals & 3 & Other machineries & 0.5 \\
\hline \multicolumn{2}{|r|}{ Total } & 79.1 & & 97.3 \\
\hline
\end{tabular}

Source: Online portal of "Combating Goods and Exchange Smuggling Central Staff"

Subsidies on fuel products in 2003 were $10.6 \%$ of GDP, while the share of subsidies on essential goods in this year was $13.7 \%$ (Komijani, 2004). The subsidies on fuel products in 2003 were twice the amount of tax revenues and almost equalled oil revenues (Komijani, 2004). The price disparity, following these huge subsidies provides an attractive opportunity for smuggling. Table 3 shows the price difference of gasoline in Iran and the Persian Gulf region during the period 1995-2003. 
Table 3: Gasoline Implicit Subsidy

\begin{tabular}{c|c|c|c|c}
\hline \hline Year & $\begin{array}{c}\text { Consumption } \\
\text { (Billion Litre) }\end{array}$ & $\begin{array}{r}\text { Price in Iran } \\
\text { (rial per litre) }\end{array}$ & $\begin{array}{c}\text { FOB price } \\
\text { (rial per litre) }\end{array}$ & $\begin{array}{c}\text { Subsidy } \\
\text { (Billion rial) }\end{array}$ \\
\hline 1995 & 11.1 & 100 & 529.4 & 6491 \\
\hline 1996 & 12 & 130 & 664.5 & 6986 \\
\hline 1997 & 12.7 & 160 & 705.1 & 6916 \\
\hline 1998 & 13.69 & 200 & 1168.8 & 21513 \\
\hline 1999 & 14.2 & 350 & 1768 & 16976 \\
\hline 2000 & 15.5 & 385 & 1465.5 & 23061 \\
\hline 2001 & 16.7 & 450 & 1756 & 35175 \\
\hline
\end{tabular}

Source: Shirkavand (2004).

Another challenging issue in combating smuggling and corruption in Iran is the inefficient monitoring system and weak enforcement of law. The role of some para-statal organizations and military bodies in smuggling also complicates this issue in Iran. For example, there was a high level of smuggling in the case of the Payam international airport, North West of Tehran, which is state-owned and operated by the Islamic Revolutionary Guard Corps (IRGC). In 2005, an Iranian newspaper disclosed that "two thousand tons of goods, mainly cosmetics, performance enhancing medication, and computer electronics" entered Iran on cargo carrier Payam Air, a company owned by the transportation ministry. ${ }^{6}$ It is reported that four smuggling flights each day and as many as twice that number on holiday flights were in operation at this airport (Samii, 2005).

Invisible jetties are also another well-known example of involvement of the IRGC in smuggling. An ex-parliamentarian estimated that the IRGC smuggling might amount to $\$ 12$ billion per year. He remarked that "this smuggling business is of such magnitude that it cannot be done through donkeys or passengers", and added that "this volume is entering the country through containers and via illegal and unofficial channels such as invisible jetties supervised by strong men and men of wealth".?

\footnotetext{
6 "The Parliament Investigates the Payam Airport Case", Iran Daily (Tehran), January 9, 2005, and "Payam Airport Not Implicated in Illegal Goods Transportation", Shargh (now no longer in circulation), November 2, 2004.

${ }^{7}$ For more details on the role of IRGC in the Iranian economy see: http://www.aei.org/publications/pubID.26991/pub_detail.asp (access: 2 June 2008). Recently, a member of Iran's Judicial Inquiry and Review Commission, disclosed information about the role of high ranking officials of Iran in corruption and smuggling cases: http://www.roozonline.com/english/archives/2008/06/unprecedented_revelations_agai.html (Access 10 June 2008)
} 


\section{Review of the theoretical literature}

In the past, economists have drawn our attention to the welfare aspects of smuggling. Bhagwati and Hansen (1973) studied the welfare levels under tariffs with and without smuggling. They assumed that smuggling involves a cost difference compared to legal trade. They model the extra cost of smuggling as a real resource cost. In their approach, constant fraction of the smuggled goods is lost. We cannot observe both illegal and legal trade simultaneously in their model. If the real unit cost of smuggling is too high, then we only observe official trade or official trade will substitute by illegal trade in the opposite situation. They concluded that the achievement of a given degree of protection to domestic importable production, in the presence of smuggling, leads to lower levels of welfare than if smuggling were absent. This is due to real resource cost of smuggling, which absorbs the productive agents from official trade sector.

Pitt (1981) proposed a model of smuggling consistent with the coexistence of smuggling, legal trade and price disparity. In his model, we can observe both legal and illegal trade simultaneously. He assumes that legal trade provides a cover for smuggling. The greater the legal trade, the easier it is to hide smuggling from enforcement agencies and smuggling would be less costly. In fact, the declared amounts of imported goods are sold at the loss on the local market, which is compensated by the profits of undeclared imported goods. Furthermore, he discusses that the quantity of legal trade and tax revenues in the smuggling situation exceed that of the non-smuggling situation. He concluded that the policy of complete and effective enforcement against smuggling might not maximise the level of legal trade. The empirical question, which may arise from Pitt's theoretical debate, is whether more openness in foreign trade section may also stimulate illegal trade.

Martin and Panagariya (1984) showed that smuggling, legal trade and price disparity exist simultaneously. They modelled the economy response to increased enforcement of anti-smuggling laws. They showed that higher enforcement of law raises real per unit costs of smuggling and the domestic price of imports but lowers the absolute quantity and the share of illegal imports in total imports. However, their model does not illustrate an unambiguous effect of smuggling on the welfare. One of their major contributions is entering the real costs of smuggling as a choice variable of the firm in their model. These costs have an endogenous nature in their model. One of the empirical messages of their model is examining the effect of enforcement of law on the costs of smuggling and the price of importable goods.

Norton (1988) provided a theoretical model for smuggling of agricultural goods within EEC countries, by focusing his empirical test on the Republic of Ireland and Northern Ireland. He entered the transport cost for smuggling as well as the probability of detection into his model. He shows that an increase in the tax rate will increase the optimal choice of smuggled goods and the number of firms that are involved in this operation. As tax rates increase, intra-marginal smugglers will increase their expected rents from smuggling and the distance-margin for worthwhile smuggling will be extended. 
However, still some firms will not smuggle goods because of transport costs. His model also indicates that increasing the rate of fine in the case of detection will reduce the expected value of smugglers profits. The Norton model shows a negative relationship between the rate of fine on smuggling and the amount of smuggled goods on one side, and positive links between increased taxes and tariffs on legal imports and the amount of smuggled products on the other side.

Thursby et al. (1991), proposed a model where smuggling is camouflaged by legal sales. This is in line with Pitt (1981) argument. They want to evaluate the effects of market structure and enforcement of law on smuggling and welfare. According to their model, cover effect in which official trade provides a cover for smugglers reduces the market price of imported goods. If these prices effects outweigh the extra real costs of smuggling, then smuggling will be pro-welfare. In this latter scenario, increasing enforcement of law may reduce the welfare. Similar to the Pitt model, their model may explain the increase of illegal trade alongside the legal one and more openness in foreign trade. Specifically this may happen when openness in foreign trade is not accompanied by necessary transparency in the foreign trade operational process.

\section{Empirical Methodology}

In this study, a specific form of structural equation modelling (e.g. Multiple Indicators Multiple Causes) is used. MIMIC estimates the relationship between observable variables and the latent variable by minimizing the distance between the sample covariance matrix $\mathbf{S}$ and the covariance matrix $\boldsymbol{\Sigma}(\boldsymbol{\theta})$ predicted by the model. Formally, the MIMIC model consists of two parts: the structural equation model and the measurement model. The structural equation model is given by: $\eta=\gamma^{\prime} \mathbf{x}+\varsigma$,

Where $\mathbf{x}^{\prime}=\left(x_{1}, x_{2}, \ldots, x_{q}\right)$ is a $(1 \times q)$ vector and each $x_{i}, i=1, \ldots, q$ is a potential cause of the latent variable $\eta$ (smuggling). $\gamma^{\prime}=\left(\gamma_{1}, \gamma_{2}, \ldots, \gamma_{q}\right)$ is a $(1 \times q)$ vector of coefficients in the structural model describing the "causal" relationships between the smuggling and its causes. Thus, the latent variable $\eta$ is linearly determined by a set of exogenous causes. Since they only partially explain the latent variable $\eta$, the error term $\varsigma$ represents the unexplained component. The MIMIC model assumes that the variables are measured as deviations from their mean and that the error term does not correlate to the causes, i.e. $\mathbf{E}(\eta)=\mathbf{E}(\mathbf{x})=\mathbf{E}(\varsigma)=0$ and $\mathbf{E}\left(\mathbf{x} \varsigma^{\prime}\right)=\mathbf{E}\left(\varsigma \mathbf{x}^{\prime}\right)=0$. The variance of $\varsigma$ is abbreviated by $\psi$ and $\boldsymbol{\Phi}$ is the $(q \times q)$ covariance matrix of the causal variables. The measurement model represents the link between the latent variable (smuggling) and its indicators; i.e. smuggling is expressed in terms of observable variables. It is specified by:

$$
\mathbf{y}=\lambda \eta+\varepsilon
$$

Where $\mathbf{y}^{\prime}=\left(y_{1}, y_{2}, \ldots, y_{p}\right)$ is a $(1 \times p)$ vector of indicator variables $y_{j}, j=1, \ldots, p . \boldsymbol{\varepsilon}^{\prime}=\left(\varepsilon_{1}, \varepsilon_{2}, \ldots, \varepsilon_{p}\right)$ is a $(1 \times p)$ vector of disturbances where every $\varepsilon_{j}, j=1, \ldots, p$ is a white noise error term. Their 
$(p \times p)$ covariance matrix is given by $\boldsymbol{\Theta}_{\varepsilon}$. The single $\lambda_{j}, j=1, \ldots, p$ in the $(p \times 1)$ vector of regression coefficients $\lambda$ represents the magnitude of the expected change of the respective indicator for a unit change in the latent variable. Like the MIMIC model's causes, the indicators are directly measurable and expressed as deviations from their mean, i.e. $\mathbf{E}(\mathbf{y})=\mathbf{E}(\boldsymbol{\varepsilon})=0$. Moreover, it is assumed that the error terms in the measurement model do not correlate either to the causes $\mathbf{x}$ or to the latent variable $\eta$, hence $\mathbf{E}\left(\mathbf{x \varepsilon ^ { \prime }}\right)=\mathbf{E}\left(\mathbf{\varepsilon} \mathbf{x}^{\prime}\right)=0$ and $\mathbf{E}\left(\eta \boldsymbol{\varepsilon}^{\prime}\right)=\mathbf{E}\left(\boldsymbol{\varepsilon} \eta^{\prime}\right)=0$. A final assumption is that the $\boldsymbol{\varepsilon}_{s}^{\prime}$ do not correlate to $\zeta$, i.e. $\mathbf{E}\left(\boldsymbol{\varepsilon} \varsigma^{\prime}\right)=\mathbf{E}\left(\varsigma \boldsymbol{\varepsilon}^{\prime}\right)=0$. The model can be resolved as a function of the observed variables by substituting equation 1 into 2 :

$y=\Pi x+\mathrm{z}$

Where the endogenous variables $y_{j}, j=1, \ldots, p$ are the latent variable $\eta$ 's indicators and the exogenous variables $x_{i}, i=1, \ldots, q$ are its causes. $\Pi=\lambda \gamma^{\prime}$ is a matrix with rank equal 1 and $\mathbf{z}=\lambda \zeta+\boldsymbol{\varepsilon}$. The error term $\mathbf{z}$ in equation (3) is a $(p \times 1)$ vector of linear combinations of the white noise error terms $\varsigma$ and $\boldsymbol{\varepsilon}$ from the structural equation and the measurement model, i.e. $\mathbf{z} \sim(\mathbf{0}, \boldsymbol{\Omega})$. The covariance matrix $\boldsymbol{\Omega}$ is given as $\operatorname{Cov}(\mathbf{z})=\mathbf{E}\left[(\boldsymbol{\lambda} \varsigma+\boldsymbol{\varepsilon})(\boldsymbol{\lambda} \varsigma+\boldsymbol{\varepsilon})^{\prime}\right]=\lambda \lambda^{\prime} \psi+\boldsymbol{\Theta}_{\boldsymbol{\varepsilon}}$ being similarly constrained like $\boldsymbol{\Pi}$. Therefore the estimation of the model requires the normalization of one of the elements of the vector, to an a priori value (Bollen, 1989). The model's covariance matrix extracted by equations 1 and 2 is given by:

$\boldsymbol{\Sigma}(\boldsymbol{\theta})=\left(\begin{array}{cc}\lambda\left(\gamma^{\prime} \boldsymbol{\Phi} \gamma+\psi\right)+\boldsymbol{\Theta}_{\varepsilon} & \lambda \gamma^{\prime} \boldsymbol{\Phi} \\ \boldsymbol{\Phi} \gamma \lambda^{\prime} & \boldsymbol{\Phi}\end{array}\right)$

This matrix describes the relationship between the observed variables in terms of their covariances. Since the latent variable is not observable, its size is unknown, and the parameters of the model must be estimated using the links between the observed variables' variances and covariances. Thus, the goal of the estimation procedure is to find values for the parameters and covariances that produce an estimate for $\boldsymbol{\Sigma}(\boldsymbol{\theta}), \hat{\boldsymbol{\Sigma}}=\boldsymbol{\Sigma}(\hat{\boldsymbol{\theta}})$, that is as close as possible to the sample covariance matrix $\mathbf{S}$ for the observed causes and indicators, i.e. the $\mathbf{x}$ s and $\mathbf{y}$ s. The estimation procedure deriving the parameters minimizes the following fitting function:

$F=\ln |\boldsymbol{\Sigma}(\boldsymbol{\theta})|+\operatorname{tr}\left[\mathbf{S} \boldsymbol{\Sigma}^{-1}(\hat{\boldsymbol{\theta}})\right]-\ln |\mathbf{S}|-(p+q)$.

The first step in the MIMIC model estimation is to confirm the hypothesized relationships between the latent variable and its causes and indicators. Once we have identified and estimated these relationships and the parameters, the MIMIC model results can be used to calculate the latent variable scores. Next, with the help of the exogenous calculation of the relative size of smuggling in trade with the trade discrepancy approach, the ordinal scores of smuggling transform to cardinal scores and finally we 
estimate the absolute amount of smuggling. Figure 2 illustrates the hypothesized path diagram of general MIMIC model.

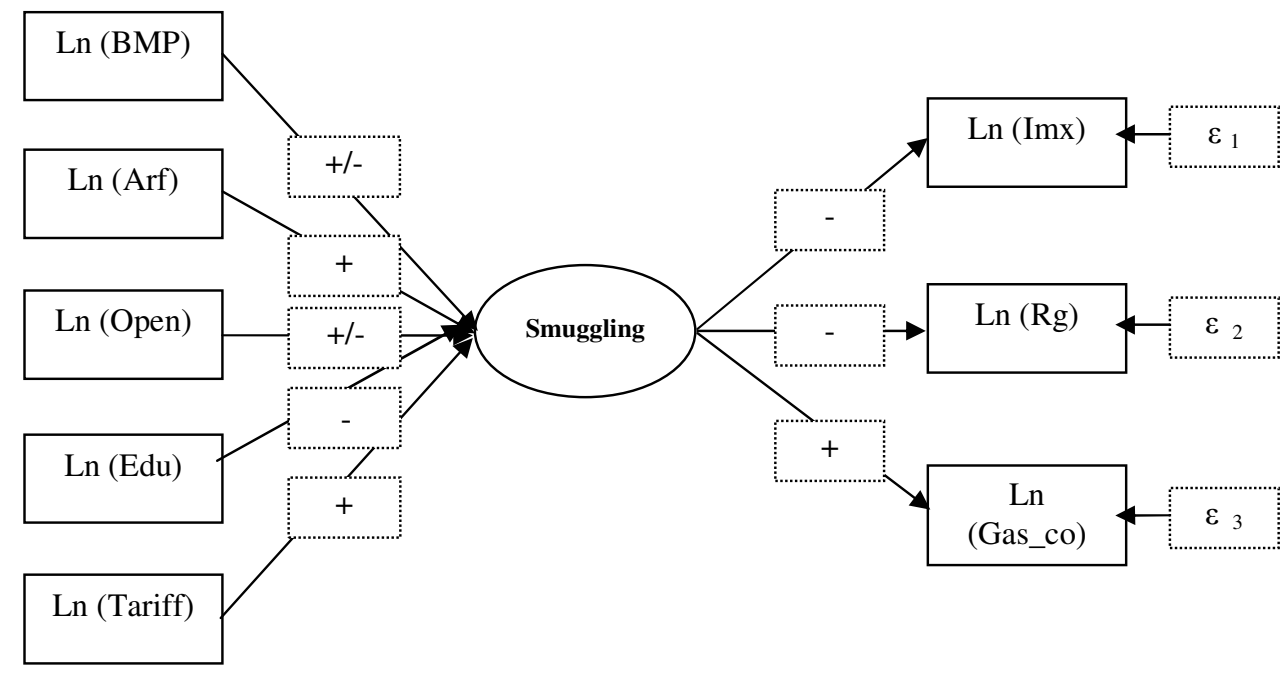

Figure 2: Hypothesized Path Diagram

\section{Model Variables}

\subsection{Causes (or determinants) of smuggling}

\subsubsection{Black Foreign Exchange Market Premium (BMP)}

Macedo (1987) constructed a detailed model of the relationship between trade taxes, smuggling and black markets in foreign exchange. The behaviour of importers and exporters, and their choice between legal trade and smuggling is the basis of this analysis. Smuggled imports are paid for with black market foreign exchange obtained from undetected smuggled exports. Since smuggled imports must be paid for with the black market foreign exchange, importers' choices between smuggling and legal trade depend not only on the level of the import tariff and the probability of detection, but also on the black market premium. In fact, for the import smuggler, the black market exchange rate is a part of his illegal financing costs. Increasing premiums for this kind of smuggling means increasing costs of operation and a reduction in import smuggling will be expected. Barnett (2003) is endorsed the above argument in a model which agents decides to become smuggler or entrepreneur on the base of premium in black market of foreign exchange. The idea behind his model is that for low amount of premium, it is cheap for agents to acquire foreign exchange in the parallel market. However, these models assume that illegal traders do not access to subsidized official exchange rate through banking system. According to Pitt (1981), legal trades are usually are cover for illegal trades. Therefore, in the case of organized smuggling, well-connected traders use official banking system and subsidized 
foreign exchange to finance their imports. In the latter case, existence of high premium in black market encourages traders to over-invoice their imports, selling the extra and illegal acquired subsidized exchange in the black market. In this case, we may expect to consider the positive effect of BMP on the import smuggling.

While illegal importers are one of main demanders in the black market of foreign exchange, the flow supply of foreign exchange into this market is generated partly by illegal exporters through underinvoicing of their exports. Thus, the amount of export smuggling will increase as the export tax rate and BMP increase. Therefore, we expect a positive effect of this variable on export smuggling. In summary, two kinds of evidence suggest a strong link between illegal trade and the black premium.

Firstly, trade data comparisons find that increases in the premium generate greater under-invoicing of exports and over-invoicing of the imports (McDonald, 1985). Secondly, studies based on export supply functions find that a rise in the black premium tends to reduce exports as domestic companies resort to mis-invoicing or smuggling (Kiguel and O`Connel, 1995). The large amount of premium was one of the critical economic channelling over the post-revolution period. Between 1979 and 1989, the premium was rising at an average annual rate of $42.1 \%$ (Pesaran, 1992). In 1992, the black market rate for the dollar reached its peak 22 times the official rate (Central Bank of Iran, 2008). This unusually great premium achieved under strict control of foreign exchange in most years after the revolution. High premium provided a unique opportunity for rent-seeking activities and illegal trade. An importer with access to subsidized official exchange rate 22 times blow the black market has a great incentive for over invoicing of imports or under invoicing of exports for easy and immediate profit. After a long period of wasting the economic resources due to multiple exchange rates and highly overvalued official exchange rate, the government unified the exchange rates and depreciated the official exchange in 2002. This institutional decision removed the black market premium largely. We define the premium as a percentage difference between the black market of exchange rate for US dollar and the official exchange rate. The source of official and black exchange rates is the central bank of Iran.

\subsubsection{Penalty on Smuggling}

In the literature, the most popular determinants of smuggling are the rate of fine, punishment and enforcement of law (Martin et al., 1983 and Norton, 1988). In this study, the rate of fine on smuggling equals the Iranian rial amount of every US dollar smuggled goods adjusted for inflation. The real rate of fine before revision of smuggling punishment codes by the Expediency Council of Iran in 1994 was very low and negligible. The real rate of penalty in 1994 increased by 46 times compared with its pervious year. The common hypothesis is that an increase in the rate of fine increases transaction costs of the smuggling and reduces the expected profit. Therefore, a negative sign for the parameter associated with this variable is expected. The average growth rate of penalty rate for the prerevolution period (1970-79), the Iraq-Iran war period (1980-1988), and the post-war period (19892002) is $-15.3,-3.06$, and 331 percent, respectively. The source of penalty data is Madah and Pajoyan (2005). 


\subsubsection{Tariff Burden}

Faced with high trade taxes or restrictions, traders often resort to illegal ways of conducting trade, such as smuggling and mis-invoicing of exports and imports. There is a large body of theoretical and empirical literature showing that taxes and restrictions lead to under-invoicing, smuggling, rentseeking and other forms of directly unproductive activities.8 Phylaktis (1992) demonstrated the positive effects of this variable on individuals' incentives for smuggling in Chile. Oskoee and Goswami (2003) also used the tariff rate as a proxy of smuggling in their panel data study for 70 developing countries. Furthermore, these trade restrictions cause price disparity among domestic and international markets and those mark-ups on imported goods provide an incentive for illegal imports and tariff evasion (Pitt, 1981). Whenever a country imposes such restrictions, domestic prices differ from the world market price, which may provide an incentive for smuggling. We define tariff burden as the ratio of real import tax on real imports. The average of tariff burden for the pre-revolution period (1970-79), the Iraq-Iran war period (1980-1988), and the post-war period (1989-2006) is 14 , 11, and 8 percent, respectively. The average share of import tax in total tax revenues over similar time intervals are 39, 31, and 27 percent (Central Bank of Iran, 2008). This declining trend of tariff burden is expected to channelize some part of illegal trade to legal one. The source of this data is the central bank of Iran.

\subsubsection{GDP per capita}

We might expect that as a country becomes richer, she might purchase or invest in the institutions and agencies needed to provide the information to better monitor the officials, for example in foreign trade sector (Rosendorff and Doces, 2006). Thus, we expect a negative effect on smuggling. However, we also expect that increasing income per capita increases the effective demand for both legal and illegal imports. In the latter case, the income effect of an increasing GDP may cause growth in the market of illegal imports, too. Meanwhile, Braun and Di Tella, 2004 and Frechette, 2006 support the positive effects of increasing income on corruption related activities. Braun and Di Tella (p. 3) explain that this is due to the pro-cyclical nature of corruption related activities, where "moral standards are lowered during booms, as greed becomes the dominant force for economic decision". The average of real GDP per capita growth for the pre-revolution period (1970-79), the Iraq-Iran war period (1980-1988), and the post-war period (1989-2005) is 5, -5.01, and 3.42 percent, respectively. The source of this data is the central bank of Iran data.

\subsubsection{Openness}

Besides an index for trade integration, this ratio also measures the revealed trade policy of government

\footnotetext{
${ }^{8}$ See for examples, Anam (1982), Bhagwati (1964), Bhagwati and Hansen (1973), Bhagwati and Srinivason (1973), Johnson (1974), Krueger (1974), Sheikh (1974), and Pitt (1981).
} 
(Helleiner, 1990). The openness ratio cannot only be affected by trade restrictions but also changes when the foreign exchange reserves or exchange rates fluctuate. This measure, therefore, shows the actual performance of foreign trade in a country. Trade liberalization, of course, will enhance the process of integration into global markets and one may expect to consider lower incentives for smuggling. However, trade liberalization requires transparency and efficient enforcement of law to impede increasing illegal trade under the cover of legal trade. As Pitt (1981) predicted, the greater the legal trade, the easier it is to hide smuggling from enforcement agencies and smuggling would be less costly. This issue will be more serious when the foreign trade section and customs lack transparency and enforcement of the law is weak. The Iranian experience on the increase of illegal imports through free trade zones refers to such institutional shortages for benefiting from more trade openness (Arabmazar, 2007). Following conventional practices in most of the literature on globalization, trade integration is calculated as [non-oil exports + imports]/non-oil GDP. The average of openness index for the pre-revolution period (1970-79), the Iraq-Iran war period (1980-1988), and the post-war period (1989-2004) is 40, 41, and 31 percent, respectively. The data for calculation of this index are from central bank of Iran.

\subsubsection{Education}

In combating corruption related activities such as smuggling, not only do we need transparency within the government but also publicity. Transparency means accessibility of information, while publicity refers to whether the information is actually been accessed by citizens. Understanding the available information through more transparency is conditioned by the general level of education in the society. Transparency without educated people is like expanding press freedom without giving people the required tools for analyzing the raw data in the press.

In sum, education increases the ability of society to control the government behaviour and to judge their performance. Educated society also plays an important role as an external control on corruption in the government administration (Brunetti and Weder, 2003; Ades and Di Tella, 1999). Finally, the negative relationship between education and corruption is well investigated in the literature. (Treismann, 2000; Ali and Isse, 2003; Alt and Lassen, 2003; Rauch and Evan, 2000; to name a few). The average level of education, measured by literacy rate, for the pre-revolution period (1970-79), the Iraq-Iran war period (1980-1988), and the post-war period (1989-2006) is 44, 59.9, and 80.3 percent, respectively. The source of this data is the central bank of Iran.

In order to control for the oil price shock of 1974, the special socio-economy situation during the revolution and war with Iraq (1979-1988), revision of the penalty codes on smuggling in 1994, and unification of exchange rates and high devaluation of the rial against US dollar in 2002, we have defined a dummy variable. 


\subsection{Indicators}

\subsubsection{The Real Governmental Revenue}

Smuggling has a significant impact on government revenues. We can assume that total governmental revenue is a function of national income $(\mathrm{Y})$. Increasing national income can be a sign of business prosperity and higher levels of obtainable taxes. In addition, increasing legal imports lead to higher levels of tax on imports revenues. Consequently, we expect that the government's revenues (GR) also increase $[(\mathrm{GR}=\mathrm{F}$ (national income, legal imports) $]$. By assuming that total domestic demand $(\mathrm{Q})$ is met by legal import and illegal imports, we have $[\mathrm{Q}=$ legal imports + illegal imports] and [GR= F(national income, Q - illegal imports)]. According to this assumption, total government revenues will be reduced by an increasing flow of illegal trade mainly because of tariff evasion by smugglers. Meanwhile, export smuggling and mis-invoicing have a negative effects on the government revenues. They usually export highly subsidized goods such as gasoline or mis-invoicing their real exports to benefit from attractive bonuses or black market premium. These subsides financed through oil and tax revenues by the government. The average growth rate of government revenues (oil, tax and other revenues) for the pre-revolution period (1970-79), the Iraq-Iran war period (1980-1988), and the postwar period (1989-2006) is 38.44, 5.23, and 36.87 percent, respectively. The source of this data is the central bank of Iran.

\subsubsection{Import Price Index}

The Import Price Index (IPI) measures price changes of goods purchased from other countries. Theoretical discussion for IPI-smuggling relationship can be found in Thursby et al. (1991). Their model indicates that if the price effect of smuggling is greater than its cost, then it is possible that smuggling improves the welfare. Thus combating smuggling might reduce the consumer welfare. In addition, Martin and Panagariya (1993) examined the enforcement law against smuggling which results in increasing per unit cost of smuggling and domestic prices of imports.

Through the evasion of legal duties and tariffs, smugglers have a cost advantage compared to legal importers in the domestic market. Therefore, they are able to earn their expected profit margin with lower prices than the market equilibrium price. Depending on the share of smuggled product in the domestic market, the market equilibrium price of that product will decline. The average growth rate of import price index for the pre-revolution period (1971-79), the Iraq-Iran war period (1980-1988), and the post-war period (1989-2005) is 10, 16, and 22 percent, respectively. The data for this index is from the central bank of Iran.

\subsubsection{Consumption of Gasoline}

The idea of using this variable as one of the indicators of smuggling roots in heavy subsidy of fuel products in Iran. This causes a considerable price disparity among Iran and the other neighbouring countries such as Turkey, Pakistan and Afghanistan. For example, according to the director general of 
Iran's Customs Administration, crude oil and oil products accounted for over 90\% of goods smuggled from Iran over the years 2000-2005. According to records for the population of different provinces in Iran, the per capita consumption of gasoline in border provinces was 10-60\% higher than in central provinces. In addition, according to the ex-cabinet secretary of Iranian government, each year more than five billion litres of fuel - mainly gasoline - is smuggled out of the country. It costs the state about 1.13 billion USD each year. ${ }^{9}$ However, other key factors affect the consumption of gasoline too. These factors are real GDP per capita, number of cars per 1000 persons, and the current and the last period of real gasoline prices. I estimate the gasoline consumption with instrumental variable method. The independent variables explain about $90 \%$ of fluctuations of gasoline consumption. The residuals show us an unexplained part of gasoline consumption by mentioned factors. I assume then that smuggling affects positively this part of unexplained consumption in gasoline. Appendix A presents details of variables, definitions and sources.

\section{Estimation and Results}

All causes and indicators except the dummy are in natural logarithm and standardized from the mean. Estimation of the structural part of the model provides ordinal estimations of smuggling, which then calibrated with the exogenous information obtained from the trade discrepancy method, which enables us to examine the relative and then absolute amount of smuggling in trade. Table 4 presents estimations for five specifications.

The tariff burden in all specifications that were included has a positive and significant effect on smuggling. Its coefficient is also stable across specifications 1, 2 and 5 . The penalty rate on smuggling has entered into models in its inverse form. This is done to make the distribution of this variable normal. The effect of the inverse of this variable on smuggling is always positive and significant. Thus, the relation between the penalty rate itself and smuggling is clearly negative. Except for the specifications 3 and 4 where its size was reduced, in the other cases the coefficient of this variable is stable.

The black exchange market premium encourages and discourages smuggling in different specifications. In specifications 1,2 , and 5 where we include the tariff burden, BMP has a negative effect on smuggling. This means that by increasing the premium, the financing costs of import smuggling will increase, too. In other words, the import underinvoicer should pay more for importing the unreported parts of his imports. In specifications 3 and 4 when we exclude tariff burden, the increasing premium encourages engaging in illegal trade. In this case, the effecting channel of BMP is through export smuggling. The export smuggler has more incentive to under invoice his real exports and sell the unreported export earnings on the black market of the foreign exchange. In specifications 1 and 2, we have also controlled for real GDP per capita. The sign is positive but not significant. The

\footnotetext{
${ }^{9}$ See: www.entrepreneur.com/tradejournals/article/print/131345258.html (access: 3 April 2008)
} 
positive sign of this variable shows that increasing income per capita increases demand for both legal and illegal imports within the domestic market and not necessarily increasing the investment in better institutions and transparency in Iran.

The openness index, which measures the magnitude of legal trade controlling for the size of the economy, has a negative but not significant effect on smuggling in specification 2. However, in specifications 3 and 4, it has a positive and significant effect on smuggling. This supports the theoretical debates of Pitt (1981) and Thursby et al. (1991), that legal trade camouflages smuggling. Increasing legal trade through more openness reduces the cost of smuggling or mis-invoicing the real price or quantity of products.

The effect of the general level of education on mitigation of smuggling in specifications 3 and 4 is evident and highly significant. This result highlights the importance of investing in human resources which enables people to engage more in the process of decision making and questioning the government for more accountability. More education also provides better opportunities in legal activities, which in turn deters the workforce from smuggling.

In the measurement part of the model, scaling the latent variable of smuggling to one of indicators with a correct sign is necessary for the identification of such a model. The real import price index in all specifications, except specification 4 , is selected as a scale variable and fixed to $-1 .{ }^{10}$ In order to check the robustness of estimations, in specification 4, the real government revenue is opted for the scale variable and fixed to -1 . In sum, the effect of smuggling on real government revenue and real import price index (in specification 4 ) is negative and significant. ${ }^{11}$

The effect of smuggling on the gasoline consumption is positive but not significant. However, when we include the growth rate of petroleum products consumption (not reported here), this positive effect will be also significant. Finally, taking into account the signs and significancy of estimates as well as general fit indices; we selected models 3 and 5 for estimating the ordinal index of smuggling. The ordinal index of smuggling, then, is calculated according to both specifications 3 and 5 . The index of smuggling is estimated on the base of specifications 3 and 5 as follows: ${ }^{12}$

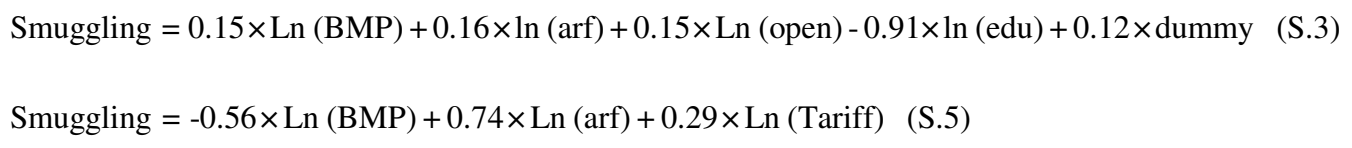

\footnotetext{
${ }^{10}$ We expect that increasing smuggling reduces the price of imported goods. However, as indicated by Stapleton (1978), the choice of the indicator fixing the scale of the latent variable is to some extent arbitrary but does not affect the results.

${ }^{11}$ When we use real tax on import revenues instead of real government revenues, the effect of smuggling is still negative but not significant (not reported here) and it will reduce the general fitness of models, too.

${ }^{12}$ Before estimation of MIMIC models, the variables are tested for stationary. Most of them are not stationary at the levels. Therefore, we have carried out Johanson cointegration test, showing that the variables are cointegrated. The Unit root and Johanson cointegration results are reported in Appendix C. Furthermore, analysis of normality and residuals of models 3 and 5 are reported in Appendix D and E, respectively.
} 
To calibrate the model and obtain a cardinal series, an exogenous estimation of smuggling in foreign trade is required in one of the years of sample. In this due, I have estimated the total mis-invoicing in Iran's export and import with her major trading partners. ${ }^{13}$ We estimate misinvoicng of Iranian trade through the following equations:

Export Misinvoicing $=\mathrm{X}_{\mathrm{i}}-\mathrm{X}_{c} \times \mathrm{CIF}$ Factor

Import Misinvoicing $=\mathrm{M}_{\mathrm{c}}-\mathrm{M}_{\mathrm{i}} \times \mathrm{CIF}$ Factor

where

$\mathrm{X}_{\mathrm{i}}$ are imports from Iran as reported by her major trading partners;

$\mathrm{X}_{\mathrm{c}}$ are exports as reported by Iran (FOB prices) to her trading partners;

$\mathrm{M}_{\mathrm{c}}$ are imports as recorded by Iran with her trading partners;

$\mathrm{M}_{\mathrm{i}}$ are exports to Iran as recorded by her trading partners.

CIF is the cost, insurance and freight costs, while FOB refers to free on board without transport costs. Imports and exports are in CIF and FOB prices. In order to make imports and exports comparable, we add $10 \%$ to exports figures which is suggested by IMF (1993). The calculation of trade discrepancy was carried out for the period of 1988-2006. When the result in the equation 8 is negative, then we have over-invoicing of exports by Iranians and positive outcomes refer to the under-invoicing of exports. When the result is positive in equation 9, it refers to the over-invoicing of imports by Iranians, and in the case of a negative result, we will have under-invoicing of imports. Gulati (1987) and McDonald (1985) have argued that both reported exports and imports may be biased because of deliberate mis-invoicing in order to bypass controls, tariff evasion and/or to facilitate capital flights. Although the reasons behind these discrepancies are not exclusively due to mis-invoicing, one can estimate the illegal practices in foreign trade through such systematic discrepancies. Tables B1-B3 (Appendix B) show import, export, and total mis-invoicing in Iran. Yavari (2000) also calculated import mis-invoicing in Iran for the period of 1988-1997. His calculation is illustrated in table B4 (Appendix B). The figures in his calculation are approximately close to our calculation of import misinvoicing for the same period. The differences may be due to different trade weights and trade partners, which are used in his analysis.

I use the figure in the year 1993 as a share of total mis-invoicing in the total trade of Iran. This leads to the relative size of mis-invoicing in the foreign trade of Iran equal to $12.74 \%$. We use this figure for calibration of the ordinal index of smuggling derived from structural equations (equations 6 and 7). The relative size of smuggling in total trade in the specifications 3 and 5 is illustrated in figure 3 . We can observe a declining trend of relative size of smuggling in both specifications. Generally, the higher

${ }^{13}$ The IMF authorities provided the author with this information regarding the major trading partners of Iran, estimating the real effective exchange rate of Iran on the base of these trade weights. 
amount of smuggling is calculated from 1970 to 1988. The main reason behind this relative higher smuggling can be seen in higher real tariff burden, negligible real penalty for smuggling, higher premium in black market, and lower education level. Since 1988 and by initiation of economic construction development plans and gradual elimination of non-tariff barriers, revision of penalty rates, higher general education and relative reduction in black market premium, we observe a lower amount of smuggling in Iran.

The estimated relative size of smuggling enables us to calculate the absolute amount of illegal trade in Iran. Table B5 (Appendix B) presents the estimated amount of smuggling over 1988-2002 on the base of specifications 3 and 5. The average of the absolute amount of smuggling in specifications 3 and 5 is 2820 and 2474 million USD, respectively. Specification 3 shows a steady decrease in the share of smuggling in the Iranian trade from $16 \%$ in 1970 to just above $11 \%$ in 2002 . The average size of smuggling in trade over this period is about $14 \%$. According to specification 5, the relative size of smuggling for the period of 1970-1984 is nearly stable around $13 \%$, reducing to about $11 \%$ at the end of period. The average size of smuggling in trade for this specification is about $12 \%$.

Tables B6 and B7 (Appendix B) show that the causal variables with most effect on the smuggling are education in specification 3 and penalty rate in specification 5. An increase in standard deviation of literacy rate reduces smuggling by 0.94 standard deviations, while the increasing penalty rate by one standard deviation reduces smuggling by 0.58 standard deviation. We calculate the five-years average of causal variables of specifications 3 and 5 as well as the smuggling share in trade in order to understand the reasons behind the dynamic of the smuggling size in Iran. The five-year growth averages are presented in table B8 (Appendix B).

In specification 3, the share of smuggling in trade (five years average growth) is negative over the total period except the last two years of 2001 and 2002. The major fall in the relative size of smuggling happened during 1991-1995. The reason behind this significant reduction is an increase in the real penalty rate on smuggling. In the year 1994, the Expediency Council of Iran revised the punishment codes against smuggling and increased the fine rate substantially. In the last two years of 2001 and 2002 , we observe that the relative size of smuggling increases by $0.20 \%$. This is mainly caused by a decrease in the real penalty rate growth and increasing openness in trade, which stimulate the import of illegal products. This is in line with the predictions of the Pitt (1981) model.

In specification 5, we have used the fine rate, BMP and tariff burden for the construction of the index. The difference with pervious specification can be seen in the average figure of positive growth of smuggling in trade over the period 1970-1980. For the remaining time horizon, the qualitative trend is similar to the pervious specification. Over the period of 1971-1975, the relative size of smuggling increased by $0.30 \%$. Although during this period, the tariff burden decreased on average by $14 \%$ but at the same time the real fine rate reduced by $24 \%$. Over the period of 1976-1980, the increase in the relative size of smuggling in trade is more than its last five years' average, accounting for $0.41 \%$. The 
main driver of this increase was the growth in the tariff burden by about $13 \%$ and of course, the negative growth of the real fine rate stimulated the rise of smuggling. Similar to specification 3 , the largest decrease in the relative size of smuggling happens during the period 1991-1995, on average. The major reason behind this decrease was a significant increase in the real fine rate on smuggling as well as an increasing black market premium by $99 \%$. The latter increased the financing costs of illegal imports and in this specification; it has a negative effect on the relative size of smuggling. However, the reduction trend in smuggling stopped at the end of 2000. We can consider the increasing size of smuggling on average by $6 \%$ over the last two years of 2001 and 2002. The main driver of this development is a reduction in the real penalty rate on smuggling and a reduction in financing the costs of illegal imports, e.g. fall of BMP following the unification of exchange rates in 2002.

\section{Conclusions}

The size and absolute amount of smuggling in the total trade of Iran has been estimated by applying MIMIC modelling and the trade discrepancy method over the period of 1970-2002. On the base of two different specifications, the annual absolute amount of smuggling for the period 1988-2002 approaches $\$ 3$ billion on average. Furthermore, the relative size of smuggling in trade on average over the period 1970-2002 is $13 \%$. The main points from standardized effects of causal on smuggling and smuggling on indicators are as follows:

- Real penalty rates (the Iranian rial per every US dollar smuggled goods) have the most significant effect on smuggling. 1 standard deviation (SD) increase in fine rate leads to a decrease in smuggling by $0.58 \mathrm{SD}$.

- $1 \mathrm{SD}$ increase in the literacy rate reduces smuggling by (0.94). 1 SD increase in BMP and legal trade (as a share in GDP) increase smuggling by 0.15 for each of them.

- The major effect of smuggling is for the reduction of the import price index. 1 SD increase in smuggling reduces this index by (1.25) and (0.97). The negative effect on real government revenue is smaller than the reduction in import price index.

It is worthy to note that our macro model of smuggling identifies the main elements that have potential effects on the latent variable of smuggling and the major consequences of increasing smuggling in the economy. We tried to control for major institutional effects as well as exogenous shocks like oil prices, war, revolution and unification of exchange rates over the period of study. However, the future studies should also consider the role of para-statal and military organizations in illegal trade. 
Table 4: Estimations of MIMIC-model

\begin{tabular}{|c|c|c|c|c|c|}
\hline Specification & 1 & $\overline{22}$ & 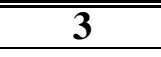 & $\overline{4}$ & $\overline{5}$ \\
\hline $\begin{array}{l}\text { Causes } \\
\text { Ln (BMP) }\end{array}$ & $\begin{array}{l}-0.56^{* * *} \\
(-5.56)\end{array}$ & $\begin{array}{l}-0.56^{\text {*** }} \\
(-4.26)\end{array}$ & $\begin{array}{c}0.15 * * * \\
(3.72)\end{array}$ & $\begin{array}{l}0.08^{\text {*** }} \\
(2.69)\end{array}$ & $\begin{array}{l}-0.56^{* * *} \\
(-5.54)\end{array}$ \\
\hline Ln (A_rate of fine) & $\begin{array}{c}0.74 * * * \\
(7.20)\end{array}$ & $\begin{array}{c}0.74 * * * \\
(5.16)\end{array}$ & $\begin{array}{c}0.16 * * * \\
(3.76)\end{array}$ & $\begin{array}{c}0.09 * * \\
(2.71)\end{array}$ & $\begin{array}{c}0.74 * * * \\
(7.44)\end{array}$ \\
\hline Ln (Tariff Burden) & $\begin{array}{l}0.28^{* * *} \\
(3.08)\end{array}$ & $\begin{array}{c}0.28^{* * * *} \\
(2.99)\end{array}$ & & & $\begin{array}{l}0.29^{* * * *} \\
(3.18)\end{array}$ \\
\hline Ln (RGDPPC) & $\begin{array}{c}0.03 \\
(0.36)\end{array}$ & $\begin{array}{c}0.03 \\
(0.35)\end{array}$ & & & \\
\hline Ln (Open) & & $\begin{array}{c}-0.01 \\
(-0.04)\end{array}$ & $\begin{array}{c}0.15^{* * * *} \\
(4.51)\end{array}$ & $\begin{array}{c}0.08 * * \\
(2.96)\end{array}$ & \\
\hline Ln(education) & & & $\begin{array}{c}-0.91 * * * \\
(-28.76)\end{array}$ & $\begin{array}{c}-0.52 * * * \\
(-3.86)\end{array}$ & \\
\hline Dummy & $\begin{array}{c}0.09 \\
(0.45) \\
\end{array}$ & $\begin{array}{c}0.09 \\
(0.45) \\
\end{array}$ & $\begin{array}{c}0.12 * * \\
(2.87) \\
\end{array}$ & $\begin{array}{c}0.07 * * \\
(2.31) \\
\end{array}$ & $\begin{array}{c}0.07 \\
(0.33) \\
\end{array}$ \\
\hline \multicolumn{6}{|l|}{ Indicators } \\
\hline $\begin{array}{l}\text { Ln (Import Price } \\
\text { Index) }\end{array}$ & -1.00 & -1.00 & -1.00 & $\begin{array}{c}-1.76 * * * \\
(-3.80)\end{array}$ & -1.00 \\
\hline $\operatorname{Ln}(\mathrm{rg})$ & $\begin{array}{l}-0.36^{* *} \\
(-2.05)\end{array}$ & $\begin{array}{l}-0.37^{* *} \\
(-2.07)\end{array}$ & $\begin{array}{c}-0.57^{* * * *} \\
(-3.80)\end{array}$ & -1.00 & $\begin{array}{l}-0.36^{* *} \\
(-2.00)\end{array}$ \\
\hline Ln (Gas_cons) & $\begin{array}{c}0.05 \\
(0.49)\end{array}$ & $\begin{array}{l}0.05 \\
(0.49)\end{array}$ & $\begin{array}{c}0.16 \\
(0.97)\end{array}$ & $\begin{array}{c}0.28 \\
(0.95)\end{array}$ & $\begin{array}{c}0.03 \\
(0.35)\end{array}$ \\
\hline \multicolumn{6}{|c|}{ Goodness of Fit Indices } \\
\hline RMSEA $^{\mathrm{a}}$ & 0.00 & 0.00 & $\mathbf{0 . 0 0}$ & 0.00 & 0.00 \\
\hline p-value & 0.94 & 0.94 & 0.96 & 0.96 & 0.98 \\
\hline $\mathrm{GFI}^{\mathrm{c}}$ & 0.88 & 0.86 & 0.89 & 0.89 & 0.93 \\
\hline $\mathrm{AGFI}^{\mathrm{d}}$ & 0.83 & 0.81 & 0.84 & 0.85 & 0.89 \\
\hline $\mathrm{NFI}^{\mathrm{e}}$ & 0.70 & 0.67 & 0.85 & 0.85 & 0.82 \\
\hline
\end{tabular}

Note. (a): The RMSEA shows how well the model, with unknown but optimally chosen parameter values, would fit the population covariance matrix if it were available. Values less than 0.05 are indicators of a good fit.

(b): P-value also tests the hypothesis H0: RMSEA $<0.05$.

(c): This index ranges between 0 and 1 . The GFI $>0.90$ is usually taken as reflecting acceptable fits.

(d): GFI adjusted for a degree of freedom.

(e): Normed Fit Index (NFI), which has the range of 0-1. The larger amount is better. 


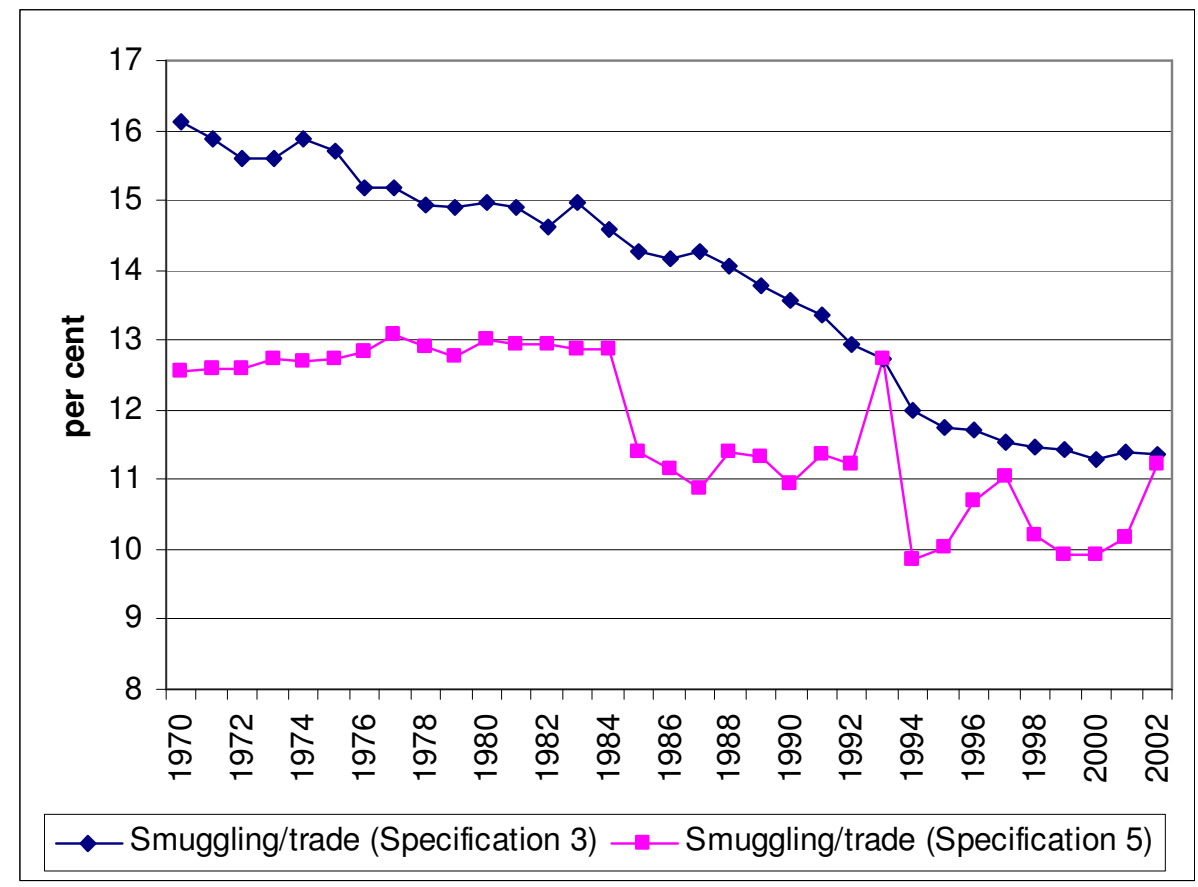

Figure 3: Smuggling as a percentage of total trade (1970-2002)

\section{References}

Ades, Alberto and Rafael Di Tella (1999): "Rents, Competition, and Corruption”, American Economic Review, Vol.89, No.4, pp.982-992.

Alano, B. (1984): "Import Smuggling in the Philippines: An Economic Analysis", Journal of Philippine Development, Vol.XI, No.2, pp.157-189.

Ali, M. Abdiweli and Hodan Said Isse (2003): "Determinants of Economic Corruption: A Cross-Country Comparison”, Cato Journal, Vol.22, No.3, pp.449-466.

Alt, James E. and David Dreyer Lassen (2003): "The Political Economy of Corruption in American Sates", Journal of Theoretical Politics, Vol.15, No.3, pp.341-365.

Anam, M. (1982):"Distortion-triggered lobbying and welfare: A contribution to the theory of directly unproductive profit-seeking activities”, Journal of International Economics, Vol. 13, pp.15-32.

Arabmazar, A. (2007). Black Economy in Iran. Tahghighat va Tosehe Olome Ensani (Research and social science development institute) Publication: Tehran, Iran.

Barnett, R. (2003):“Smuggling, Non-Fundamental Uncertainty, and Parallel Market Exchange Rate Volatility”, The Canadian Journal of Economics, Vol.36, No.3, pp.701-727.

Bhagwati, J. (1964): "On the under invoicing of imports", Bulletin of the Oxford University Institute of Statistics, Vol. 26, pp. 389-397. 
Bhagwati,J. and Bent Hansen (1973): "A Theoretical Analysis of Smuggling“, The Quarterly Journal of Economics, Vol. 87, No. 2, pp. 172-187.

Bhagwati, J. and T.N. Srinivasan (1973): “Smuggling and Trade Policy', Journal of Public Economics, Vol. 2 No.4, pp.377-89.

Biswas, A. and Sugata Marjit (2007): "Preferential trade and mis-invoicing: Some analytical implications", International Review of Economics \& Finance, Volume 16, No.1, pp. 130-138

Bollen, K. A. (1989): “Structural equations with latent variables”. New York: John Wiley \& Sons.

Braun, M. and Rafael Di Tella (2004): "Inflation, Inflation Variability, and Corruption “, Economic and Politics, Vol.16, No.1, pp.77-100.

Brunetti, A.and Beartrice Weder (2003): “A Free Press is Bad News for Corruption", Journal of Public Economics, Vol.87, No.7, pp.1801-1824.

Central Bank of Iran (2008): "The first edition of the CBI Time Series Economic Database". Available at: http://tsd.cbi.ir/IntTSD/EnDisplay/Display.aspx (Access: 4 June 2008).

Combating Goods and Exchange Smuggling Central Staff (2008), Available in Persian at: http://eqtesadepenhan.com/comments.asp?category=12\&id=36 (Access: 4 June 2008).

Deflem, M. and Kelly Henry-Turner (2001). "Smuggling, The Encyclopaedia of Criminology and Deviant Behaviour", Clifton D. Bryant, Editor-in-Chief. Volume 2, Crime and Juvenile Delinquency, Philadelphia, PA: Brunner-Routledge.

Diamantopoulos, A. and Judy Siguaw, (2000). Introducing LISREL: A Guide for the Uninitiated. Sage Publications, London.

Doing Business in Iran (2008): Available at: http://www.doingbusiness.org/Documents/CountryProfiles/IRN.pdf (Access: 4 June 2008).

Dominguez, J. (1975): “Smuggling”, Foreign Policy, No. 20, pp. 87-96+161-164.

Dornbusch, R. et al (1983): "The Black Market for Dollars in Brazil," The Quarterly Journal of Economics, Vol. 98, No.1, pp. 25-40.

Frechette, G. (2006): “A Panel Data Analysis of the Time-Varying Determinants of Corruption”, CIRANO Working Paper 28.

Gulati,S.K. (1987): “ A note on the trade mis-invoicing”, In: Lessard, D.R. and Williamson, J., Editors, 1987. Capital flight and third world debt, Institute for International Economics, Washington, D.C., pp.68-78.

Helleiner, G. K. (1990): “Trade strategy in medium-term adjustment", World Development, Vol. 18, No.6, pp. 879-897.

IMF (1993): A Guide to Direction of Trade Statistics. Available at: http://www.esds.ac.uk/international/support/user_guides/imf/DOTGuide.pdf (Access 4 June 2008). 
Johnson, H. (1974): "Notes on the economic theory of smuggling", Malayan Economic Review (1972). In J.Bhagwati ed. reprint on Illegal Transactions in International Trade, Amsterdam: NorthHolland..

Kiguel, M. and Stephen A. O'Connell (1995): "Parallel Exchange Rates in Developing Countries", The World Bank Research Observer, Vol.10, pp.21-52.

Komijani, A. (2004): "Measuring the economic effects of cash payment of subsidies", In: Economics of Subsidy Forum Proceeding, Imam Sadegh University, Tehran, Iran.

Krueger, A. (1974): „The Political Economy of the Rent-Seeking Society”, American Economic Review, Vol. 69, No. 3, pp.291-303.

Lithuanian Free Market Institute (2004): “A Study on Economic Causes of Smuggling”, Available at: http://www.freema.org/Projects/Smuggling.pdf

Macedo, J.B.D (1987):“Currency Incontrovertibility, Trade Taxes and Smuggling”, NBER Working Paper No. W2177.

Madah, M. and Jamshid Pajoyan (2005):“Economic Review of Smuggling in Iran”, Pajoheshnameh Eghtesadi, No.20, pp.43-70 (Farsi).

Martin, L. and Arvind Panagariya (1984): "Smuggling, Trade and Price Disparity: A Crime Theoretic Approach", Journal of International Economics, Vol. 17, No.3/4, pp.201-17.

McDonald, D.C. (1985):“Trade discrepancies and the incentives to smuggle”, IMF Staff Papers, 32, pp.668692.

Merriman, D. (2003): “Understanding, Measure, and Combat Tobacco Smuggling”, Toolkit No. 7, World Bank.

Morgenstern, O. (1950): "On the accuracy of economic observations: Foreign trade statistics", in: The Accuracy of Economic Observations, Chapter IX, Princeton University Press.

Naya, S. and Theodore Morgan (1969): “The accuracy of international trade data: The case of South East Asian countries“, Journal of the American Statistical Association, Vol. 64, No. 326, pp. 452-467 .

Norton, D. (1988): “On the Economic Theory of Smuggling”, Economica, Vol. 55, No. 217, pp. 107-118.

Oskooee, B: and Gour G. Goswami (2003):“Smuggling and the Black Market Premium”, Scientific Journal of Administrative Development, Vol. 1, No.1, pp.95-111.

Pesaran, H. (1992): “The Iranian Foreign Exchange Policy and the Black Market for Dollars”, International Journal of Middle East Studies, Vol. 24, No.1, pp.101-125.

Pitt, M. (1981): "Smuggling and price disparity", Journal of International Economics, Vol. 11, No.4, pp. 447-458.

Phylaktis, K. (1991): “The Black Market for Dollars in Chile”, Journal of Development Economy, Vol: 37, No.1-2, pp.155-172. 
Rauch, J. and Peter Evans (2000): "Bureaucratic Structure and Bureaucratic Performance in Less Developed Countries", Journal of Public Economics, Vo.75, No.1, pp.49-71.

Rosendorff,P. and John Doces (2006): “Democracy and Transparency, Swiss Political Science Review, Vol. 12, No. 3, pp. 99-112.

Samii, B. (2005): “Analysis: Goods Smuggling Highlights Economics Problems in Iran”, Radio Free Europe /Radio Liberty, Available at: http://www.parstimes.com/news/archive/2005/rfe/goods smuggling.html (Access 4 June 2008).

Sheikh, M. (1974): "Smuggling, Protection, and Welfare", Journal of International Economics, Vol.4, No.4, pp.355-64.

Shirkavand, S. (2004): "Trend of subsidies in Iran and the effects of cash payment of subsidies", In: Economics of Subsidy Forum Proceeding, Imam Sadegh University, Tehran, Iran.

Stapleton, D. (1978): “Analyzing political participation data with a MIMIC Model”, Sociological Methodology, Vol. 15. pp. 52-74.

Thursby, M., Richard Jensen and Jerry Thursby (1991): "Smuggling, Camouflaging, and Market Structure", The Quarterly Journal of Economics, Vol. 106, No. 3, pp. 789-814.

Treisman, D. (2000): “The Causes of Corruption: A Cross-National Study", Journal of Public Economics, Vol: 76, No: 3, pp.399-457.

Valadkhani, A. (2004): “An Empirical Analysis of the Black Market Exchange Rate in Iran”, Faculty of Commerce, University of Wollongong. Available at: http://works.bepress.com/abbas/27/.

Yavari, K. (2000):“Estimation of smuggling and over-invoicing in import section: the case of Iran", The 3rd National Forum on Smuggling, University of Tarbiat Modarres, Faculty of Economics, Tehran, Iran.

\section{Appendix A}

Table A1. Data explanation

\begin{tabular}{cccc}
\hline \hline Variables & Definition & Transformation & Source \\
\hline Fine rate & USD value of smuggled goods, & -The inverse form of \\
fine rate is used & -standardized from mean & Madah and Pajoyan \\
& adjusted for inflation & & \\
& & & \\
& & & \\
BMP & The difference between official & -percentage & Central Bank of Iran \\
\hline \hline
\end{tabular}




\begin{tabular}{|c|c|c|c|}
\hline & $\begin{array}{l}\text { and black exchange rate for } \\
\text { USD/rial }\end{array}$ & $\begin{array}{l}\text {-logarithmic form } \\
\text {-standardized from mean }\end{array}$ & $\begin{array}{c}\text { online database: } \\
\text { www.cbi.ir }\end{array}$ \\
\hline Tariff burden & $\begin{array}{l}\text { The ratio of real tax on } \\
\text { imports/ real imports }\end{array}$ & $\begin{array}{l}\text {-logarithmic form } \\
\text {-standardized from mean }\end{array}$ & $\begin{array}{c}\text { Central Bank of Iran } \\
\text { online database }\end{array}$ \\
\hline RGDPPC & Real GDP per capita & $\begin{array}{l}\text {-logarithmic form } \\
\text {-standardized from mean }\end{array}$ & $\begin{array}{c}\text { Central Bank of Iran } \\
\text { online database }\end{array}$ \\
\hline Openness & $\begin{array}{c}\text { Non-oil exports+imports/non- } \\
\text { oil GDP }\end{array}$ & $\begin{array}{l}\text {-logarithmic form } \\
\text {-standardized from mean }\end{array}$ & $\begin{array}{c}\text { Central Bank of Iran } \\
\text { online database }\end{array}$ \\
\hline Education & Literacy rate & $\begin{array}{l}\text {-logarithmic form } \\
\text {-standardized from mean }\end{array}$ & $\begin{array}{c}\text { Central Bank of Iran } \\
\text { online database }\end{array}$ \\
\hline Import price index & Real Import price index & $\begin{array}{l}\text {-logarithmic form } \\
\text {-standardized from mean }\end{array}$ & $\begin{array}{c}\text { Central Bank of Iran } \\
\text { online database }\end{array}$ \\
\hline RG & Real government revenues & $\begin{array}{l}\text {-logarithmic form } \\
\text {-standardized from mean }\end{array}$ & $\begin{array}{c}\text { Central Bank of Iran } \\
\text { online database }\end{array}$ \\
\hline Gas_cons & Gasoline consumption & $\begin{array}{c}\text { Residual from } \\
\text { regression of gasoline } \\
\text { consumption on real } \\
\text { current and past gasoline } \\
\text { prices, real GDP per } \\
\text { capita, number of cars } \\
\text { per } 1000 \text { persons } \\
\text {-logarithmic form } \\
\text {-standardized from mean }\end{array}$ & $\begin{array}{c}\text { Various reports of } \\
\text { Ministry of petroleum } \\
\text { of Iran }\end{array}$ \\
\hline
\end{tabular}

\section{Appendix B: Estimating smuggling by trade discrepancy methodology}

Mis-invoicing of import and export between Iran and her major 19 trading partners (e.g. Australia, Austria, Brazil, Canada, China, P.R.: Mainland, France, Germany, Hungary, India, Indonesia, Italy, Japan, Netherlands, Saudi Arabia, Sweden, Switzerland ,Turkey, UAE , and UK). The amount of trade with these countries is used by the IMF to calculate the real effective Exchange Rate of Iran for recent years. The main differences between import and export figures usually arise because most exports are recorded on an F.O.B. basis and most imports on C.I.F. The difference represents the cost of transport and insurance. Therefore we have to adjust the export figures by adding $10 \%$ to the original value of exports. The 10\% factor is an approximate value of the costs of the insurance and freight (IMF, 1993). Mis-invoicing and fraud usually play a significant role in the remaining discrepancies in figures. 
Table B 1: Import Mis-invoicing (Million USD)

\begin{tabular}{c|c|c}
\hline \hline Year & Under-invoicing of imports & Over-invoicing of imports \\
\hline 1988 & 849.223 & \\
\hline 1989 & & 1353.0626 \\
\hline 1990 & & 1302.2909 \\
\hline 1991 & & 4526.6547 \\
\hline 1992 & & 4184.4239 \\
\hline 1993 & 183.4126 & $\mathbf{2 9 2 2 . 7 8 4 6}$ \\
\hline 1995 & & 73.1655 \\
\hline 1996 & 380.2756 & 647.7069 \\
\hline 1997 & & 474.3407 \\
\hline 1998 & & 377.1785 \\
\hline 1999 & & 53.1018 \\
\hline 2000 & & 168.1432 \\
\hline 2001 & & 2148.758 \\
\hline 2002 & & 2.88 \\
\hline 2003 & & \\
\hline 2004 & & \\
\hline 2006 & 0.0212 & \\
\hline
\end{tabular}

Source: Raw trade figures of Iran with major trading partners from DOT (IMF) and calculation of misinvoicing from author.

Table B 2: Export Mis-invoicing (Million USD)

\begin{tabular}{c|c|c}
\hline Year & Under-invoicing of exports & Over-invoicing of exports \\
\hline 1988 & & 1563.162 \\
\hline 1989 & & 2256.979 \\
\hline 1990 & & 3421.792 \\
\hline 1991 & & 196.216 \\
\hline 1992 & $\mathbf{1 6 9 . 7 8 8}$ & 753.651 \\
\hline $\mathbf{1 9 9 3}$ & & 2482.787 \\
\hline 1994 & & 1043.547 \\
\hline 1995 & & 2577.244 \\
\hline 1996 & & 1507.081 \\
\hline 1997 & & 1531.743 \\
\hline 1998 & & 3343.953 \\
\hline 1999 & & 0.0118 \\
\hline 2000 & & 0.0029 \\
\hline 2001 & & 0.002 \\
\hline 2002 & & 7.9798 \\
\hline 2003 & & 0.0264 \\
\hline 2004 & & 0.0369 \\
\hline 2005 & & \\
\hline \hline
\end{tabular}

Source: Raw trade figures of Iran with major trading partners from DOT (IMF) and calculation of misinvoicing from author. 
Table B3: Total Mis-invoicing (Million USD)

\begin{tabular}{c|c}
\hline \hline Year & Total mis-invoicing \\
\hline 1988 & -2412.39 \\
\hline 1989 & -903.916 \\
\hline 1990 & -2119.5 \\
\hline 1991 & 4330.439 \\
\hline 1992 & 3430.773 \\
\hline $\mathbf{1 9 9 3}$ & $\mathbf{3 0 9 2 . 5 7 3}$ \\
\hline 1994 & -2666.2 \\
\hline 1995 & -970.382 \\
\hline 1996 & -1929.54 \\
\hline 1997 & -1887.36 \\
\hline 1998 & -1057.4 \\
\hline 1999 & -2966.77 \\
\hline 2000 & 53.09 \\
\hline 2001 & 168.1403 \\
\hline 2002 & 2148.756 \\
\hline 2003 & -5.0998 \\
\hline 2004 & 86.6928 \\
\hline 2005 & -0.0476 \\
\hline
\end{tabular}

Source: Raw trade figures of Iran with major trading partners from DOT (IMF) and calculation of misinvoicing from author.

Table B4: Mis-invoicing of Imports (1988-1997)

\begin{tabular}{c|c|c}
\hline \hline Year & Under-invoicing of imports & Over-invoicing of imports \\
\hline 1988 & 1306.8 & 329.6 \\
\hline 1989 & & 453.8 \\
\hline 1990 & & 3212.8 \\
\hline 1991 & & 231.5 \\
\hline 1992 & & $\mathbf{2 4 6 0 . 9}$ \\
\hline $\mathbf{1 9 9 3}$ & & 181 \\
\hline 1994 & & 454.8 \\
\hline 1995 & 876.3 & 809.3 \\
\hline 1996 & & \\
\hline \hline
\end{tabular}

Source: Yavari (2000)

Table B5: Absolute Amount of Smuggling (Million USD)

\begin{tabular}{c|c|c}
\hline Year & Smuggling S.3 & Smuggling S.5 \\
\hline 1988 & 1706.012 & 1382.017 \\
\hline 1989 & 2430.946 & 1997.837 \\
\hline 1990 & 3723.415 & 3001.683 \\
\hline 1991 & 4249.629 & 3619.34 \\
\hline 1992 & 4261.335 & 3699.233 \\
\hline 1993 & 3092.573 & 3092.573 \\
\hline 1994 & 2267.222 & 1863.521 \\
\hline 1995 & 2158.584 & 1844.75 \\
\hline 1996 & 2630.886 & 2398.433 \\
\hline 1997 & 2432.637 & 2323.788 \\
\hline \hline
\end{tabular}




\begin{tabular}{c|c|c}
\hline \hline 1998 & 2039.769 & 1818.11 \\
\hline 1999 & 2480.813 & 2154.558 \\
\hline 2000 & 2519.207 & 2211.849 \\
\hline 2001 & 2791.209 & 2492.933 \\
\hline 2002 & 3256.807 & 3218.418 \\
\hline Average & $\mathbf{2 8 0 2 . 7 3 6}$ & $\mathbf{2 4 7 4 . 6 0 3}$ \\
\hline \hline
\end{tabular}

Source: Own calculation

Table B6: Total effects of model 3

\begin{tabular}{|c|c|c|c|c|c|}
\hline \multicolumn{6}{|c|}{ Standardized total effects of X on ETA } \\
\hline & LnBMP & LnARF & LnOPEN & LnEDU & Dummy \\
\hline Smuggling & 0.15 & 0.16 & 0.15 & -0.94 & 0.06 \\
\hline \multicolumn{6}{|c|}{ Standardized total effects of ETA on Y } \\
\hline \multicolumn{6}{|c|}{ Smuggling } \\
\hline LnIM & -0.97 & & & & \\
\hline LnRG & -0.55 & & & & \\
\hline LnGAS_CO & 0.15 & & & & \\
\hline
\end{tabular}

Table B7: Total effects of model 5

\begin{tabular}{|c|c|c|c|c|}
\hline \multicolumn{5}{|c|}{ Standardized total effects of X on ETA } \\
\hline & LnBMP & LnARF & LnTARIFF & Dummy \\
\hline Smuggling & -0.45 & 0.58 & 0.23 & 0.02 \\
\hline \multicolumn{5}{|c|}{ Standardized total effects of ETA on Y } \\
\hline & Smugglir & & & \\
\hline LnIM & -1.25 & & & \\
\hline LmRG & -0.44 & & & \\
\hline LnGAS_CO & 0.05 & & & \\
\hline
\end{tabular}

Table B8: Five-year average of annual growth rates

\begin{tabular}{c|c|c|c|c|c|c|c}
\hline \hline Year & $\begin{array}{c}\text { Fine rate } \\
(\mathrm{S} 3 \& 5)\end{array}$ & $\begin{array}{c}\text { BMP } \\
(\mathrm{S} \\
3 \& 5)\end{array}$ & $\begin{array}{c}\text { Tariff } \\
\text { burden } \\
(\mathrm{S} 5)\end{array}$ & $\begin{array}{c}\text { Openness } \\
(\mathrm{S} 3)\end{array}$ & $\begin{array}{c}\text { Education } \\
(\mathrm{S} 3)\end{array}$ & $\begin{array}{c}\text { Smuggling/Trade } \\
\text { Specification3 }\end{array}$ & $\begin{array}{c}\text { Smuggling/Trade } \\
\text { Specification5 }\end{array}$ \\
\hline $\begin{array}{c}1971- \\
1975\end{array}$ & -23.523 & 0 & -14.252 & 17.83 & 5.2 & -0.52 & 0.30 \\
\hline $\begin{array}{c}1976- \\
1980\end{array}$ & -10.447 & 43.16 & 12.984 & -0.08 & 4.2 & -0.92 & -0.41 \\
\hline $\begin{array}{c}1981- \\
1985\end{array}$ & 21.386 & 27.13 & 0.634 & -3.63 & 1.7 & -1.00 & -0.79 \\
\hline $\begin{array}{c}1986- \\
1990\end{array}$ & -9.125 & 28.66 & -6.140 & 0.51 & 3.4 & -2.84 & -0.93 \\
\hline $\begin{array}{c}1991- \\
1995\end{array}$ & 913.951 & 99.59 & 4.954 & 5.29 & 2.1 & -0.76 & -0.11 \\
\hline $\begin{array}{c}1996- \\
2000\end{array}$ & 5.707 & 25.03 & 18.011 & -5.88 & 1.3 & & \\
\hline $\begin{array}{c}2001- \\
2002\end{array}$ & -10.169 & -51.29 & 4.386 & 15.51 & 0.3 & 0.20 & 6.37 \\
\hline \hline
\end{tabular}

Source: Own calculation 


\section{Appendix C: Unit-Root and Cointegration Tests}

Following the guidelines of Breusch (2005) which asserts that with integrated or tending data, the levels of variables are strongly informative. If there is cointegration, the strategy of estimating the differences dismisses such information.

Table C1: Unit Root Tests

\begin{tabular}{|c|c|c|c|c|c|}
\hline & \multirow{2}{*}{$\begin{array}{c}\text { Included in } \\
\text { equation }\end{array}$} & \multicolumn{2}{|c|}{ Level } & \multicolumn{2}{|c|}{$1^{\text {st }}$ Diff. } \\
\hline & & $\mathrm{ADF}$ & PP & ADF & PP \\
\hline \multicolumn{6}{|c|}{ Causals } \\
\hline Ln (ARF) & $C \& T$ & -2.03 & -1.95 & $-6.09 *$ & $-6.68 *$ \\
\hline Ln (BMP) & $\mathrm{C} \& \mathrm{~T}$ & -1.29 & -1.32 & $-5.12 *$ & $-5.05 *$ \\
\hline Ln(Tariff) & $C \& \mathrm{~T}$ & -2.73 & -2.80 & $-6.09 *$ & $-6.85^{*}$ \\
\hline Ln (RGDPPC) & None & $-3.42 *$ & $-3.39 *$ & - & - \\
\hline Ln (Open) & $\mathrm{C} \& \mathrm{~T}$ & $-3.38 * * *$ & $-3.38 * * *$ & - & - \\
\hline $\operatorname{Ln}(\mathrm{Edu})$ & $\mathrm{C} \& \mathrm{~T}$ & -1.55 & -1.32 & $-3.55 * * *$ & $-3.53 * * *$ \\
\hline \multicolumn{6}{|c|}{ Indicators } \\
\hline $\operatorname{Ln}(\operatorname{Im})$ & $\mathrm{C}$ & -0.15 & 0.80 & $-2.71 * * *$ & $-2.66 * * *$ \\
\hline $\operatorname{Ln}(\operatorname{Rg})$ & $C \& \mathrm{~T}$ & -1.83 & -2.05 & $-4.52 *$ & $-4.52 *$ \\
\hline Ln(Gas_con) & None & $-6.33 *$ & $-6.57 *$ & $0.00 *$ & $0.00^{*}$ \\
\hline
\end{tabular}

Table C2: Johansen Cointegration Test

\begin{tabular}{l|l}
\hline \hline Variables $(\mathbf{n})$ & Number of Cointegrated Vectors \\
\hline $\mathrm{Ln}(\mathrm{im}), \ln (\operatorname{arf}), \ln (\mathrm{bmp}), \ln (\mathrm{edu})$ & 3 (Trace) and 2 (Max-Eigenvalue) \\
\hline $\mathrm{Ln}(\mathrm{rg}), \ln (\operatorname{arf}), \ln (\mathrm{bmp}), \ln (\mathrm{edu})$ & 2 (Trace) and 1( Max- Eigenvalue) \\
\hline \hline
\end{tabular}

\section{Appendix D: Analysis of Normality}

The following table 5 presents the tests of normality (univariate) of the variables used in MIMIC models. This test has performed by Eviews 5 software and presents the p-value of the Jarque-Bera Test. The $\mathrm{p}$-values larger than 5\% confirm the acceptance of null hypothesis, indicating normal distribution of respected variables.

Table D1: J-Bera Test (P-value) of Univariate Normality

\begin{tabular}{l|l}
\hline \hline Causes & J-Bera test (p-value) \\
\hline Ln (ARF) & 0.17 \\
\hline Ln (BMP) & 0.28 \\
\hline Ln (Edu) & 0.30 \\
\hline Ln (Open) & 0.30 \\
\hline Ln (Rgdppc) & 0.57 \\
\hline Ln (Tariff) & 0.71 \\
\hline Indicators & \\
\hline Ln (Im) & 0.19 \\
\hline Ln(Rg) & 0.51 \\
\hline Ln (Gas_cons) & 0.00 \\
\hline \hline
\end{tabular}

\section{Appendix E: Analysis of Residuals}

The analysis of residuals which is presented in table 8 and figure 5 allows the validity of the model to be accepted. Nomal probability or the Q plot which is demonstrated in figure 5 plots the standardized 
residuals (horizontal axis) against the quantiles of the normal distribution. The best possible fit would be indicated if all residuals were lying in a straight vertical line, whereas the worst possible fit would be indicated if all residuals were lying in a horizontal line. An acceptable fit is indicated when the residuals lie approximately along the diagonal, with steeper plots showing the better fits (Diamantopoulos et al. 2000). Table 8 and figure 5 allow the validity of model 3 to be accepted. The residuals obtained are small and lower than 2 . Also, the residuals are clustered symmetrically around the zero point, with most residuals lying in the middle of distribution and fewer in the tails, following an almost symmetrical positive-negative pattern. The same discussion is true for the model 5 residuals which are presented in table 9 and figure 6.

Table E1: Analysis of Residuals of the Model 3

Summary Statistics for Standardized Residuals

\begin{tabular}{ll}
\hline \hline Smallest Standardized Residual $=$ & -1.673703 \\
\hline Median Standardized Residual $=$ & 0.000000 \\
\hline Largest Standardized Residual $=$ & 1.631623 \\
\hline
\end{tabular}

Stemleaf Plot

\begin{tabular}{c}
\hline$-1 \mid 7$ \\
\hline$-1 \mid 2$ \\
\hline$-0 \mid 7$ \\
\hline$-0 \mid 2110000000000000000000000$ \\
\hline $0 \mid 111$ \\
\hline $0 \mid 8$ \\
\hline $1 \mid 111$ \\
\hline $1 \mid 6$
\end{tabular}

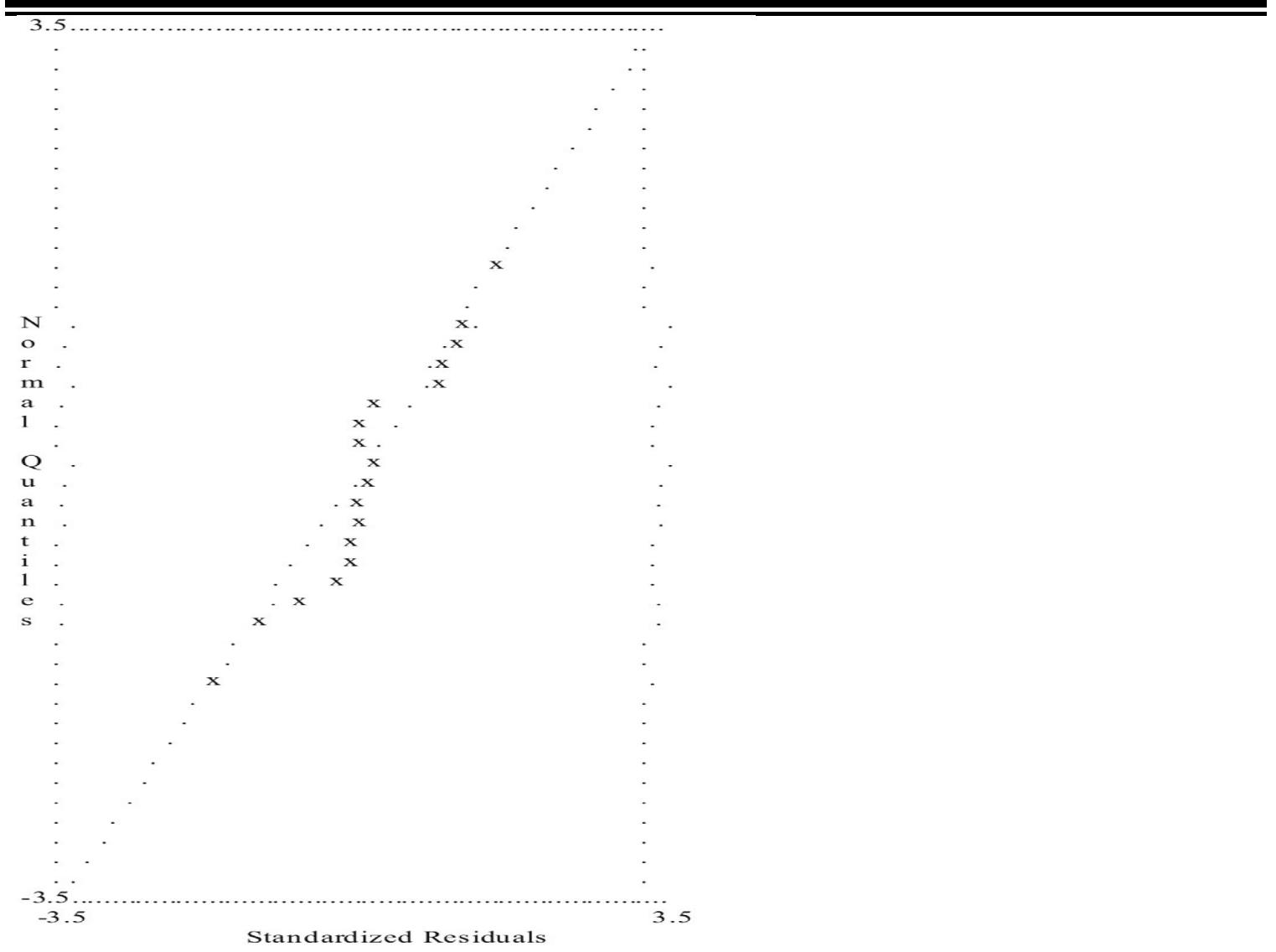

Figure 5: Q-plot diagram of standardized residuals (model 3) 
Table E2: Analysis of Residuals of the Model 5

Summary Statistics for Standardized Residuals

Smallest Standardized Residual $=-1.867640$

Median Standardized Residual $=0.000000$

Largest Standardized Residual $=1.215380$

\section{Stemleaf Plot}

\begin{tabular}{c}
\hline-1196 \\
\hline-110 \\
\hline-015 \\
\hline$-0 \mid 441000000000000000$ \\
\hline 0133 \\
\hline 01599 \\
\hline 112 \\
\hline
\end{tabular}

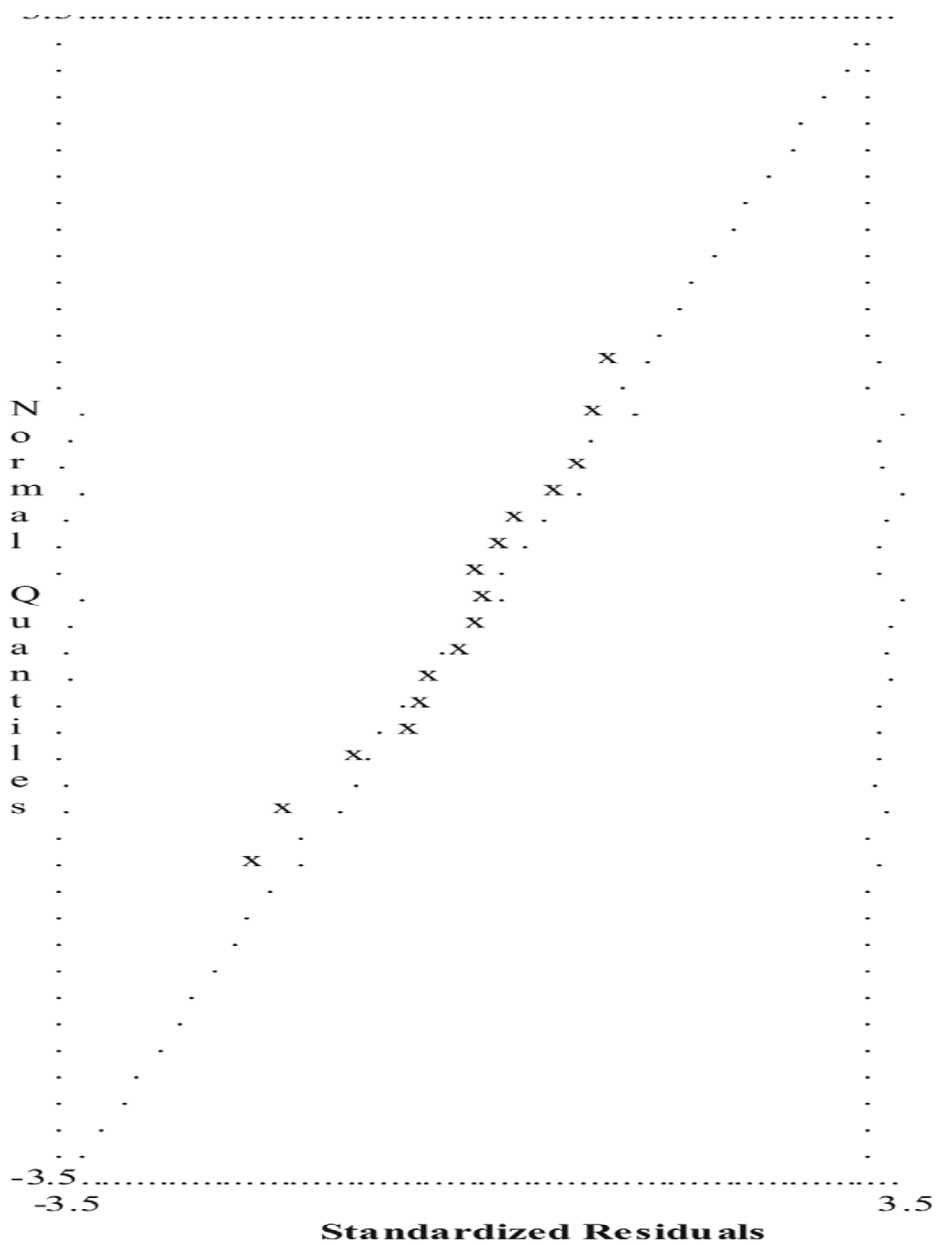

Figure 6: Q-plot diagram of standardized residuals (model 5) 


\section{CESifo Working Paper Series}

for full list see www.cesifo-group.org/wp

(address: Poschingerstr. 5, 81679 Munich, Germany, office@cesifo.de)

2333 Erkki Koskela and Panu Poutvaara, Outsourcing and Labor Taxation in Dual Labor Markets, June 2008

2334 Philippe Choné and Laurent Linnemer, Optimal Litigation Strategies with Signaling and Screening, June 2008

2335 Albert Solé-Ollé and Pilar Sorribas-Navarro, Does Partisan Alignment Affect the Electoral Reward of Intergovernmental Transfers?, June 2008

2336 Antonio Cabrales and Piero Gottardi, Markets for Information: Of Inefficient Firewalls and Efficient Monopolies, June 2008

2337 Sumon Majumdar and Sharun W. Mukand, The Leader as Catalyst - on Leadership and the Mechanics of Institutional Change, June 2008

2338 Ulrich Hange, Tax Competition, Elastic Labor Supply, and Growth, June 2008

2339 Guy Laroque and Bernard Salanié, Does Fertility Respond to Financial Incentives?, June 2008

2340 Adriano Paggiaro, Enrico Rettore and Ugo Trivellato, The Effect of Extending the Duration of Eligibility in an Italian Labour Market Programme for Dismissed Workers, June 2008

2341 Helmut Seitz, Minimum Standards, Fixed Costs and Taxing Autonomy of Subnational Governments, June 2008

2342 Robert S. Chirinko, Leo de Haan and Elmer Sterken, Asset Price Shocks, Real Expenditures, and Financial Structure: A Multi-Country Analysis, July 2008

2343 Wolfgang Leininger, Evolutionarily Stable Preferences in Contests, July 2008

2344 Hartmut Egger and Udo Kreickemeier, Fairness, Trade, and Inequality, July 2008

2345 Ngo Van Long and Bodhisattva Sengupta, Yardstick Competition, Corruption, and Electoral Incentives, July 2008

2346 Florian Baumann, Employment Protection: The Case of Limited Enforceability, July 2008

2347 Alessandro Balestrino, Cinzia Ciardi and Claudio Mammini, On the Causes and Consequences of Divorce, July 2008

2348 Dirk Schindler and Benjamin Weigert, Insuring Educational Risk: Opportunities versus Income, July 2008 
2349 Lammertjan Dam and Ben J. Heijdra, The Environmental and Macroeconomic Effects of Socially Responsible Investment, July 2008

2350 Avner Greif, Contract Enforcement and Institutions among the Maghribi Traders: Refuting Edwards and Ogilvie, July 2008

2351 Helmuth Cremer, Philippe De Donder, Dario Maldonado and Pierre Pestieau, Habit Formation and Labor Supply, July 2008

2352 Francesco Menoncin and Paolo M. Panteghini, The Johansson-Samuelson Theorem in General Equilibrium: A Rebuttal, July 2008

2353 Michael Kaganovich and Itzhak Zilcha, Alternative Social Security Systems and Growth, July 2008

2354 Keith Blackburn, Kyriakos C. Neanidis and M. Emranul Haque, Corruption, Seigniorage and Growth: Theory and Evidence, July 2008

2355 Edward Castronova, A Test of the Law of Demand in a Virtual World: Exploring the Petri Dish Approach to Social Science, July 2008

2356 Harald Badinger and Peter Egger, GM Estimation of Higher-Order Spatial Autoregressive Processes in Cross-Section Models with Heteroskedastic Disturbances, July 2008

2357 Wolfgang Buchholz and Jan Schumacher, Discounting the Long-Distant Future: A Simple Explanation for the Weitzman-Gollier-Puzzle, July 2008

2358 Luca Anderlini, Leonardo Felli and Alessandro Riboni, Statute Law or Case Law?, July 2008

2359 Guglielmo Maria Caporale, Davide Ciferri and Alessandro Girardi, Are the Baltic Countries Ready to Adopt the Euro? A Generalised Purchasing Power Parity Approach, July 2008

2360 Erkki Koskela and Ronnie Schöb, Outsourcing of Unionized Firms and the Impacts of Labour Market Policy Reforms, July 2008

2361 Francisco Alvarez-Cuadrado and Ngo Van Long, A Permanent Income Version of the Relative Income Hypothesis, July 2008

2362 Gabrielle Demange, Robert Fenge and Silke Uebelmesser, Financing Higher Education and Labor Mobility, July 2008

2363 Alessandra Casarico and Alessandro Sommacal, Labor Income Taxation, Human Capital and Growth: The Role of Child Care, August 2008

2364 Antonis Adam, Manthos D. Delis and Pantelis Kammas, Fiscal Decentralization and Public Sector Efficiency: Evidence from OECD Countries, August 2008 
2365 Stefan Voigt, The (Economic) Effects of Lay Participation in Courts - A Cross-Country Analysis, August 2008

2366 Tobias König and Andreas Wagener, (Post-)Materialist Attitudes and the Mix of Capital and Labour Taxation, August 2008

2367 Ximing Wu, Andreas Savvides and Thanasis Stengos, The Global Joint Distribution of Income and Health, August 2008

2368 Alejandro Donado and Klaus Wälde, Trade Unions Go Global!, August 2008

2369 Hans Gersbach and Hans Haller, Exit and Power in General Equilibrium, August 2008

2370 Jan P.A.M. Jacobs and Jan-Egbert Sturm, The Information Content of KOF Indicators on Swiss Current Account Data Revisions, August 2008

2371 Oliver Hülsewig, Johannes Mayr and Timo Wollmershäuser, Forecasting Euro Area Real GDP: Optimal Pooling of Information, August 2008

2372 Tigran Poghosyan and Jakob de Haan, Determinants of Cross-Border Bank Acquisitions in Transition Economies: A Latent Class Analysis, August 2008

2373 David Anthoff and Richard S.J. Tol, On International Equity Weights and National Decision Making on Climate Change, August 2008

2374 Florian Englmaier and Arno Schmöller, Reserve Price Formation in Online Auctions, August 2008

2375 Karl Farmer, Birgit Friedl and Andreas Rainer, Effects of Unilateral Climate Policy on Terms of Trade, Capital Accumulation, and Welfare in a World Economy, August 2008

2376 Monika Bütler, Stefan Staubli and Maria Grazia Zito, The Role of the Annuity’s Value on the Decision (Not) to Annuitize: Evidence from a Large Policy Change, August 2008

2377 Inmaculada Martínez-Zarzoso, The Impact of Urbanization on $\mathrm{CO}_{2}$ Emissions: Evidence from Developing Countries, August 2008

2378 Brian Roberson and Dmitriy Kvasov, The Non-Constant-Sum Colonel Blotto Game, August 2008

2379 Ian Dew-Becker, How Much Sunlight Does it Take to Disinfect a Boardroom? A Short History of Executive Compensation Regulation, August 2008

2380 Cécile Aubert, Oliver Falck and Stephan Heblich, Subsidizing National Champions: An Evolutionary Perspective, August 2008

2381 Sebastian Buhai, Miguel Portela, Coen Teulings and Aico van Vuuren, Returns to Tenure or Seniority?, August 2008 
2382 Erkki Koskela and Jan König, Flexible Outsourcing, Profit Sharing and Equilibrium Unemployment, August 2008

2383 Torberg Falch and Justina AV Fischer, Does a Generous Welfare State Crowd out Student Achievement? Panel Data Evidence from International Student Tests, September 2008

2384 Pedro Gomes and François Pouget, Corporate Tax Competition and the Decline of Public Investment, September 2008

2385 Marko Koethenbuerger, How Do Local Governments Decide on Public Policy in Fiscal Federalism? Tax vs. Expenditure Optimization, September 2008

2386 Ronald McKinnon and Gunther Schnabl, China’s Exchange Rate Impasse and the Weak U.S. Dollar, September 2008

2387 Yan-Leung Cheung, Yin-Wong Cheung and Alan T.K. Wan, A High-Low Model of Daily Stock Price Ranges, September 2008

2388 Louis Eeckhoudt and Harris Schlesinger, Changes in Risk and the Demand for Saving, September 2008

2389 Carsten Hefeker and Blandine Zimmer, Uncertainty and Fiscal Policy in an Asymmetric Monetary Union, September 2008

2390 Jay Pil Choi and Byung-Cheol Kim, Net Neutrality and Investment Incentives, September 2008

2391 Marcel Gérard, Financing Bologna, the Internationally Mobile Students in European Higher Education, September 2008

2392 Annette Alstadsæter and Knut Reidar Wangen, Corporations' Choice of Tax Regime when Transition Costs are Small and Income Shifting Potential is Large, September 2008

2393 António Afonso and Christophe Rault, 3-Step Analysis of Public Finances Sustainability: the Case of the European Union, September 2008

2394 Betsey Stevenson and Justin Wolfers, Economic Growth and Subjective Well-Being: Reassessing the Easterlin Paradox, September 2008

2395 Bernhard Eckwert and Itzhak Zilcha, Private Investment in Higher Education: Comparing Alternative Funding Schemes, September 2008

2396 Øystein Foros, Hans Jarle Kind and Jan Yngve Sand, Slotting Allowances and Manufacturers’ Retail Sales Effort, September 2008

2397 Mohammad Reza Farzanegan, Illegal Trade in the Iranian Economy: Evidence from a Structural Model, September 2008 